Late Quaternary stratigraphy, chronology, and depositional processes

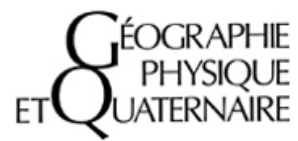
on the slope of S.E. Baffin Island, detrital carbonate and Heinrich events: Implications for onshore glacial history Stratigraphie, chronologie et mise en place des sédiments sur le talus continental du sud-est de l'île de Baffin, épisodes de dépôt de roches carbonatées détritiques et de Heinrich, au Quaternaire supérieur : implications pour l'histoire glaciaire terrestre Stratigraphie, Chronologie und Ablagerungsprozesse im späten Quartär auf dem Hang der SO-Baffin-Insel, Episoden der Ablagerung von Schutt-, Karbonat- und Heinrich-Gestein: Implikationen für die glaziale Küstengeschichte

John T. Andrews, M. Kirby, Anne E. Jennings et D. C. Barber

Volume 52, numéro 1, 1998

URI : https://id.erudit.org/iderudit/004762ar

DOI : https://doi.org/10.7202/004762ar

Aller au sommaire du numéro

Éditeur(s)

Les Presses de l'Université de Montréal

ISSN

0705-7199 (imprimé)

1492-143X (numérique)

Découvrir la revue

Citer cet article

Andrews, J. T., Kirby, M., Jennings, A. E. \& Barber, D. C. (1998). Late Quaternary stratigraphy, chronology, and depositional processes on the slope of S.E. Baffin Island, detrital carbonate and Heinrich events: Implications for onshore glacial history. Géographie physique et Quaternaire, 52(1), 91-105.

https://doi.org/10.7202/004762ar
Résumé de l'article

Plus de 40 datations au radiocarbone, obtenues sur les foraminifères issus de carottes de 2,5 à $11 \mathrm{~m}$ en provenance du talus continental du SE de l'ïle de Baffin, ont servi à décrire les interactions entre l'inlandsis et l'océan à la limite NE de l'Inlandsis laurentidien. Les taux d'accumulation de sédiments variaient entre 20 et $40 \mathrm{~cm} / \mathrm{ka}$. Six carottes contiennent un enregistrement haute résolution du stade isotopique 2 et, en partie, des stades 1 et 3 , et trois carottes ont des dates maximales $\geqslant 30 \mathrm{ka}$, ce qui éclaire les stades 3 et, peut-être, 4/5. Les carottes comprennent trois principaux faciès : le lithofaciès A est riche en roches carbonatées détritiques chamois jaunâtre (DC-events ou épisodes de CD) ; le lithofaciès B est pauvre en roches carbonatées détritiques olive ; le lithofaciès $C$ est une unité sédimentaire noire. Les faciès reflètent les changements dans l'origine des glaces, la proximité de l'inlandsis et les processus de mise en place. Les auteurs en concluent que certaines épisodes de CD sont corrélatifs aux épisodes de Heinrich (H-events) H-1, H-2 et H-4 en Atlantique Nord. Après H-4 (vers $35 \pm$ ka), l'âge est difficile à déterminer. Les couches de $\mathrm{CD}$ ont en partie été déposées à partir de courants de turbidité, de la fonte des icebergs et de la pluie de limon et d'argile à grains fins. Au contraire, les sédiments distaux de l'est de l'Atlantique Nord ont enregistré des épisodes $\mathrm{H}$ comme des accroissements soudains de particules de la grosseur des sables glaciels. Dans la région à l'étude, l'épaisseur des couches de $\mathrm{H}$ varient de 0-70 $\mathrm{cm}(\mathrm{H}-1)$ à $20-90 \mathrm{~cm}(\mathrm{H}-2) ; \mathrm{H}-4$ varient de $\geqslant 60$ à $10 \mathrm{~cm}$. Les conditions de mise en place des lithofaciès ont surtout été de nature hémipélagique (B), laissant supposer que les moments où la glace a atteint le plateau continental ont été de courte durée (A et C).
Tous droits réservés @ Les Presses de l'Université de Montréal,1998
Ce document est protégé par la loi sur le droit d'auteur. L’utilisation des services d'Érudit (y compris la reproduction) est assujettie à sa politique d'utilisation que vous pouvez consulter en ligne.

https://apropos.erudit.org/fr/usagers/politique-dutilisation/ 


\section{LATE QUATERNARY STRATIGRAPHY, CHRONOLOGY, AND DEPOSITIONAL PROCESSES ON THE SLOPE OF S.E. BAFFIN ISLAND, DETRITAL CARBONATE AND HEINRICH EVENTS: IMPLICATIONS FOR ONSHORE GLACIAL HISTORY}

John T. ANDREWS, M. KIRBY, Anne E. JENNINGS, D.C. BARBER, Institute for Arctic and Alpine Research and Department of Geological Sciences, Box 450, University of Colorado, Boulder, Colorado, 80309, U.S.A., andrewsj@spot.Colorado.edu.

ABSTRACT In order to describe ice sheet/ ocean interactions at the NE margin of the Laurentide Ice Sheet over 40 radiocarbon dates have been obtained on foraminifera from nine, 2.5 to $11 \mathrm{~m}$ piston cores from the slope of SE Baffin Island. The cores were collected off Cumberland Sound and north of Hudson Strait from 750 to 1510 m water depth. Rates of sediment accumulation varied between 20 and $40 \mathrm{~cm} / \mathrm{ky}$. Six cores contain high-resolution records of events during $\mathrm{Ma}$ rine Isotope Stage (MIS) 2 and parts of 1 and 3 , whereas three cores have core top dates of $\geq 30 \mathrm{ka}$ and thus provide information on MIS 3 and possibly $4 / 5$. The cores include three main facies: Lithofacies A - yellowish/buff detrital carbonate-rich sediment, also referred to as Detrital Carbonate (DC-) events; Lithofacies B - olive-green detrital carbonate-poor sediment; and Lithofacies C - a black sedimentary unit. The lithofacies represent changes in glacial sources, ice sheet proximity, and processes of deposition. We conclude that there are DCevents correlative with Heinrich events $\mathrm{H}-1, \mathrm{H}$ 2 , and $\mathrm{H}-4$ in the North Atlantic; however, we find no compelling evidence for a DC-layer during $\mathrm{H}-3$ (ca. $27 \pm \mathrm{ka}$ ). There are three to four distinct DC- events after $\mathrm{H}-4$ (ca. $35 \pm \mathrm{ka}$ ) but their exact ages are difficult to determine. Grain-size spectra and X-radiographs show that the DC-sediments are stratified to massive silty-clays with little sand, but generally have higher sand percentages at the base. DC-layers were deposited in part from turbidity currents, melting of icebergs, and rain-out of fine-grained silts and clays. In contrast, ice distal sediments in the eastern North Atlantic recorded $\mathrm{H}$-events as an abrupt increase in ice rafted sand-size particles. In our study area, $\mathrm{H}$-layer thicknesses vary from 0 and $70 \mathrm{~cm}$ for $\mathrm{H}-1$ and 20 to $90 \mathrm{~cm}$ for $\mathrm{H}-2 ; \mathrm{H}-4$ is $\geq 60$ to 100 $\mathrm{cm}$ thick. Over the total length of our records, the sedimentary conditions have been dominated by hemipelagic deposition (lithofacies $\mathrm{B})$, implying that those times when ice reached the shelf (lithofacies $A$ and $C$ ) have been short.
RÉSUMÉ Stratigraphie, chronologie et mise en place des sédiments sur le talus continental du sud-est de l'île de Baffin, épisodes de dépôt de roches carbonatées détritiques et de Heinrich, au Quaternaire supérieur: implications pour l'histoire glaciaire terrestre. Plus de 40 datations au radiocarbone, obtenues sur les foraminifères issus de carottes de 2,5 à $11 \mathrm{~m}$ en provenance du talus continental du SE de l'ïle de Baffin, ont servi à décrire les interactions entre l'inlandsis et l'océan à la limite NE de I'Inlandsis laurentidien. Les taux d'accumulation de sédiments variaient entre 20 et 40 $\mathrm{cm} / \mathrm{ka}$. Six carottes contiennent un enregistrement haute résolution du stade isotopique 2 et, en partie, des stades 1 et 3 , et trois carottes ont des dates maximales $\geq 30 \mathrm{ka}$, ce qui éclaire les stades 3 et, peut-être, 4/5. Les carottes comprennent trois principaux faciès : le lithofaciès $A$ est riche en roches carbonatées détritiques chamois jaunâtre (DC-events ou épisodes de $C D$ ) ; le lithofaciès $B$ est pauvre en roches carbonatées détritiques olive ; le lithofaciès $\mathrm{C}$ est une unité sédimentaire noire. Les faciès reflètent les changements dans l'origine des glaces, la proximité de l'inlandsis et les processus de mise en place. Les auteurs en concluent que certaines épisodes de CD sont corrélatifs aux épisodes de Heinrich ( $\mathrm{H}$-events) $\mathrm{H}-1, \mathrm{H}-2$ et $\mathrm{H}-4$ en Atlantique Nord. Après H-4 (vers $35 \pm k a$ ), l'âge est difficile à déterminer. Les couches de CD ont en partie été déposées à partir de courants de turbidité, de la fonte des icebergs et de la pluie de limon et d'argile à grains fins. Au contraire, les sédiments distaux de l'est de l'Atlantique Nord ont enregistré des épisodes $\mathrm{H}$ comme des accroissements soudains de particules de la grosseur des sables glaciels. Dans la région à l'étude, l'épaisseur des couches de $\mathrm{H}$ varient de $0-70 \mathrm{~cm}(\mathrm{H}-1)$ à $20-90 \mathrm{~cm}(\mathrm{H}-2)$; $\mathrm{H}-4$ varient de $\geq 60$ à $10 \mathrm{~cm}$. Les conditions de mise en place des lithofaciès ont surtout été de nature hémipélagique $(B)$, laissant supposer que les moments où la glace a atteint le plateau continental ont été de courte durée ( $A$ et $C)$.
ZUSAMMENFASSUNG Stratigraphie, Chronologie und Ablagerungsprozesse im späten Quartär auf dem Hang der SO-Baffin-Insel, Episoden der Ablagerung von Schutt-, Karbonatund Heinrich-Gestein : Implikationen für die glaziale Küstengeschichte. Um die Interaktionen von Eisdecke und Ozean am NO-Rand der laurentischen Eisdecke zu beschreiben, hat man über 40 Kohlenstoffdatierungen auf Foraminiferen von neun 2,5 bis $11 \mathrm{~m}$ tiefen Bohrkernen vom Hang der SO-Baffin-Insel durchgeführt. Die Raten der Sediment-Akkumulation variierten zwischen 20 und $40 \mathrm{~cm} / \mathrm{ka}$. Sechs Kerne enthalten hochauflösende Belege über Ereignisse während des marinen Isotopen-Stadiums 2 sowie Teile von 1 und 3 , wohingegen drei Kerne maximale Daten von 30 ka haben und so Information über das marine Isotopen-Stadium 3 und möglicherweise 4/5 liefern. Die Kerne enthalten drei Haupt-Fazies : Lithofazies A ist ein gelblich/gelbbraunes karbonatreiches SchuttSediment, das man auch als Schutt Karbonat(SK-)Ereignis bezeichnet ; Lithofazies B ist ein olivgrünes karbonatarmes Schutt-Sediment und Lithofazies $C$ ist eine schwarze Sedimenteinheit. Die Lithofazies spiegeln Wechsel in den glazialen Quellen, der Nähe der Eisdecke und den Ablagerungsprozessen. Wir schließen daraus, dass es eine Korrelation zwischen SK-Ereignissen und den Heinrich-Ereignisssen $\mathrm{H}-1$, $\mathrm{H}-2$ und $\mathrm{H}-4$ im Nordatlantik gibt ; indessen finden wir keine zwingende Evidenz für eine SKSchicht während $\mathrm{H}-3$ (ca. $27 \pm \mathrm{ka}$ ). Es gibt drei bis vier verschiedene SK-Ereignisse nach $\mathrm{H}-4$ (ca. $35 \pm \mathrm{ka}$ ), aber ihre exakten Alter sind schwer zu bestimmen. Die SK-Schichten sind zum Teil durch Dichtigkeitsströmungen, Schmelzen der Eisberge und Regen von feingekörntem Schlamm und Ton abgelagert worden. Dagegen haben eis-distale Sedimente im Osten des Nordatlantik $\mathrm{H}$-Ereignisse als eine plötzliche Zunahme in sandgroßen, durch Eis gestrandeten Teilchen aufgezeichnet. In unserem untersuchten Gebiet variiert die H-Schichtdicke zwischen 0 bis $70 \mathrm{~cm}$ für $\mathrm{H}-1$ und 20 bis $90 \mathrm{~cm}$ für H-2 ; H-4 ist 60 bis $100 \mathrm{~cm}$ dick. Über die gesamte Länge unserer Belege waren die Sedimentationsbedingungen durch hemipelagische Ablagerung (Lithofazies B) beherrscht, was darauf schließen lässt, dass die Zeiten, als das Eis das Schelf erreichte (Lithofazies A und C) von kurzer Dauer waren. 


\section{INTRODUCTION}

The extent of the last glaciation on the shelves of the Eastern Canadian Arctic (ECA) has been debated for years, and is indeed part of the larger debate on the history of Northern Hemisphere glaciation (Denton and Hughes, 1981; Fulton, 1989; Piper et al., 1991). The problem has been confounded because of two issues: 1) the identification of "tracers" that can be used to link the records of the terrestrial glacial and offshore marine environments; and 2) the need to unambiguously date that part of the sediment record that can be retrieved by piston cores.

A current issue of ice sheet/ocean interactions and dynamics (Alley and MacAyeal, 1994; MacAyeal, 1993) is the generation of Heinrich ( $\mathrm{H}-$ ) events (Andrews and Tedesco, 1992; Bond et al., 1992; Broecker et al., 1992; Dowdeswell et al., 1995; Heinrich, 1988). H-events are said to represent massive collapses of the Laurentide Ice Sheet (LIS) and the creation of "armadas of icebergs" that track across the North Atlantic; yet ice margin positions, bedrock sources, sediment transport, and mechanics of deposition are still unknown in detail (Andrews et al., 1993; Grousset et al., 1993; Gwiazda et al., 1996; Revel et al., 1996).

Cumberland Sound is a large embayment in the uplifted rim of the Eastern Canadian Arctic (Fig. 1). The elevation at the divide between Foxe Basin and Cumberland Sound is only $200 \mathrm{~m}$; thus, ice from the Foxe/Baffin dome should have flowed seaward, possibly as a major ice stream (Hughes, 1987). Reconnaissance glacial geological field work on the north side of the sound suggests that the maximum of the last (Foxe) glaciation occurred early, possibly in Marine Isotope Stage (MIS) 5 (Dyke et al., 1982; Miller, 1985; Miller and de Vernal, 1992; Miller et al., 1992), and the then current paradigm called for limited glaciation of Cumberland Sound. However, Jennings $(1989,1993)$ challenged this concept and proposed that late Foxe ice grounded in the $1200 \mathrm{~m}$ deep basin of outer Cumberland Sound. Dates from glacial marine sediments immediately overlying a basal diamicton (till) indicated that retreat was underway by ca. $10.4 \mathrm{ka}$.

The marine stratigraphic record of Cumberland Sound contains only a deglacial sequence, hence the history of ice margin prior to $10.4 \mathrm{ka}$ is unresolved. However, a series of piston cores from the slope of the NW Labrador Sea, "downstream" of Cumberland Sound and north of Hudson Strait, were mainly collected in the 1970's (but one later core HU87-033-009 is also relevant (Jennings et al., 1996)) (Table I, Fig. 2). The core sites (Figs. 1 and 2) lie only about $100 \mathrm{~km}$ east of the coast of SE Baffin Island, thus it is reasonable that they should be examined to determine what information they carry about regional ice sheet/ocean interactions. Some of these cores have been studied (e.g. Aksu and Mudie, 1985; Fillon, 1985; Pereira et al., 1988), but no radiocarbon dates were obtained. However, sufficient planktonic foraminifera existed to obtain $\mathrm{AMS}{ }^{14} \mathrm{C}$ dates at most levels in the cores (Table I) (e.g. Andrews et al., 1994a; Jennings et al., 1996). The AMS dates showed that the rates of

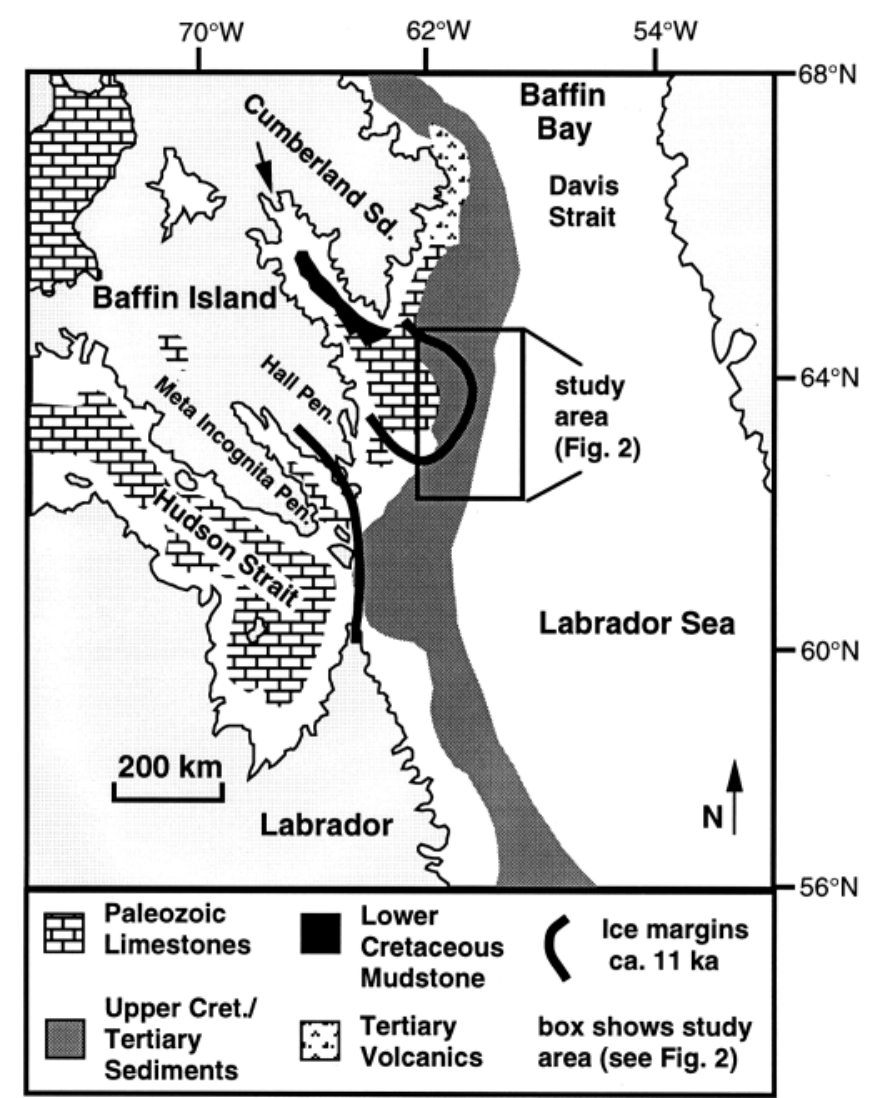

FIGURE 1. SE Baffin Island showing area of Hudson Strait and Cumberland Sound. The bedrock outcrop (MacLean, 1985) is shown as is the proposed limit of ice at 11 ka (Jennings et al., 1996; Kaufman et al., 1993).

Le sud-est de lîle de Baffin et une partie du détroit d'Hudson et de la baie de Cumberland. Le substratum (MacLean, 1985) ainsi que la marge glaciaire à 11 ka sont indiqués (Jennings et al., 1996; Kaufman et al., 1993).

sediment accumulation were much faster than had been initially proposed (Aksu and Mudie, 1985; Andrews et al., 1994a).

Aksu and Mudie (1985) showed that several of the cores we studied here contained repeated occurrences of a lithofacies (lithofacies A - see below) which is distinguished by its high detrital carbonate content. This lithofacies is identical to Detrital Carbonate (DC-) events noted by Andrews and Tedesco (1992) from the NW Labrador Sea, which in turn were demonstrated to be correlative with $\mathrm{H}$-events. An important issue is thus the identification of tracers (e.g. Balkwill et al., 1990) that would link the offshore records to onshore glacial activity. Three have been identified; i) reworked shelf foraminifera (Jennings et al., 1996), ii) sediment eroded from the submarine Cretaceous outcrop in Cumberland Sound; and iii) sediment eroded from the Paleozoic carbonate outcrop on the shelf and within the sound (Fig. 1) (Jennings, 1989, 1993).

Our objectives in this paper are to answer the following questions: 1) Can DC-events be correlated from core to core in the area of Figure 2? 2) is there a 1:1 match between DC- 
TABLE I

Core locations (Fig. 2) and radiocarbon data

\begin{tabular}{|c|c|c|c|c|c|}
\hline $\begin{array}{c}\text { Core Id } \\
\text { Core Depth }\end{array}$ & $\underset{(\mathrm{mg})}{\text { Sample Wt }}$ & $\begin{array}{l}\text { Latitude } \\
\text { Water } \\
\text { depth }(m)\end{array}$ & Lab Id & $\begin{array}{l}\text { Longitude } \\
\text { Error }\end{array}$ & $\begin{array}{c}\text { Uncorrected } \\
\text { Date }\end{array}$ \\
\hline HU75009-IV-062 & & $62^{\circ} 23.7^{\prime}$ & $59^{\circ} 18.1^{\prime}$ & & \\
\hline 145 & 6.8 & 510 & AA-10568 & 180 & 20,840 \\
\hline $298-300$ & 6.8 & & $A A-13231$ & 120 & 13,055 \\
\hline HU75009-IV-057 & TWC & $63^{\circ} 00.09^{\prime}$ & $58^{\circ} 10.79^{\prime}$ & & \\
\hline 55 & 4.1 & 999 & AA-14216 & 175 & 18,865 \\
\hline 55 & 14.1 & & AA-14204 & 160 & 19,565 \\
\hline 55 & 7.9 & & AA-14217 & 145 & 18,475 \\
\hline 55 & 1.66 & & AA-14685 & 135 & 16,800 \\
\hline HU75009-IV-57 & & $63^{\circ} 00.09^{\prime}$ & $58^{\circ} 10.97^{\prime}$ & & \\
\hline $6-10$ & 12.8 & 999 & AA-9062 & 590 & 33,170 \\
\hline $98-100$ & 13.9 & & AA-9063 & 7240 & \\
\hline $197-200$ & 13.3 & & AA-9064 & 3000 & 46,700 \\
\hline HU75009-IV-60 & & $62^{\circ} 40.6^{\prime}$ & $59^{\circ} 22.4^{\prime}$ & & \\
\hline 0 & 7.3 & 1145 & AA-4703 & 1500 & 40,700 \\
\hline $61-62$ & 10.1 & & AA-4704 & 60 & 43,200 \\
\hline $128-129$ & 3.0 & & AA-4687 & 1200 & 32,150 \\
\hline $260-261$ & 6.2 & & AA-4686 & 725 & 34,025 \\
\hline HU75009-IV-58 & & $62^{\circ} 46^{\prime}$ & $59^{\circ} 22^{\prime}$ & & \\
\hline $7-9$ & 6.5 & 1057 & $A A-5033$ & 90 & 10,530 \\
\hline 50 & & & AA-20728 & 360 & 26,525 \\
\hline $157-162$ & 5.6 & & AA-5034 & 260 & 19,070 \\
\hline 175 & NA & & AA-2642 & & $>44,550$ (shell, transported?) \\
\hline 310 & & & AA-20729 & 405 & 29,990 \\
\hline 400 & & & AA-20730 & 1820 & 31,040 \\
\hline IMP 77-1-2 & & $63^{\circ} 28.2^{\prime}$ & $59^{\circ} 06.5^{\prime}$ & & \\
\hline 145 & 3.7 & 880 & AA-14202 & 95 & 11,080 \\
\hline $247-253$ & 11.1 & & $A A-13233$ & 90 & 12,970 \\
\hline $350-352$ & 6.3 & & AA-9355 & 205 & 14,280 \\
\hline $448-458$ & 11.1 & & $A A-13234$ & 140 & 16,125 \\
\hline 795 & 15.8 & & AA-13235 & 355 & 24,365 \\
\hline $826-829$ & 5.7 & & AA-10658 & 350 & 29,055 \\
\hline IMP 77-3-2 & & $63^{\circ} 03^{\prime}$ & $59^{\circ} 07^{\prime}$ & & \\
\hline 105 & 5.0 & 915 & $A A-14218$ & 805 & 36,020 \\
\hline $137-140$ & 12.8 & & $A A-15694$ & 335 & 28,050 \\
\hline 305 & 5.5 & & $A A-14219$ & 1700 & 41,800 \\
\hline $787-790$ & 4.7 & & AA-15695 & 820 & 36,370 \\
\hline 847 & 2.6 & & AA-14220 & 970 & 36,870 \\
\hline IMP77-5-1 & & $62^{\circ} 44.52^{\prime}$ & $60^{\circ} 53.8^{\prime}$ & & \\
\hline $350-352$ & 5.4 & 750 & AA-9356 & 260 & 23,890 \\
\hline IMP76-2-1 & & $63^{\circ} 20.9^{\prime}$ & $59^{\circ} 10.9^{\prime}$ & & \\
\hline 105 & & 920 & $A A-17381$ & 190 & 12,470 \\
\hline 162 & & & AA-18383 & 155 & 14,675 \\
\hline 418 & & & $A A-17382$ & 500 & 27,210 \\
\hline 797 & & & AA-17383 & 1850 & 39,920 \\
\hline HU87033-009 LCF & & $62^{\circ} 30.99^{\prime}$ & $59^{\circ} 26.82^{\prime}$ & & \\
\hline 10 & & 1437 & AA-7136 & 380 & 10,180 \\
\hline 451 & & & AA--15659 & 130 & 11,105 \\
\hline 501 & & & AA- 8034 & 205 & 14,400 \\
\hline 501 & & & AA-9364 & 90 & 14,530 \\
\hline 601 & & & AA-20788 & 180 & 19,290 \\
\hline 651 & & & AA-18382 & 260 & 20,330 \\
\hline 711 & & & AA-13230 & 220 & 20,620 \\
\hline 973 & & & AA-01569 & 675 & 33,560 \\
\hline
\end{tabular}




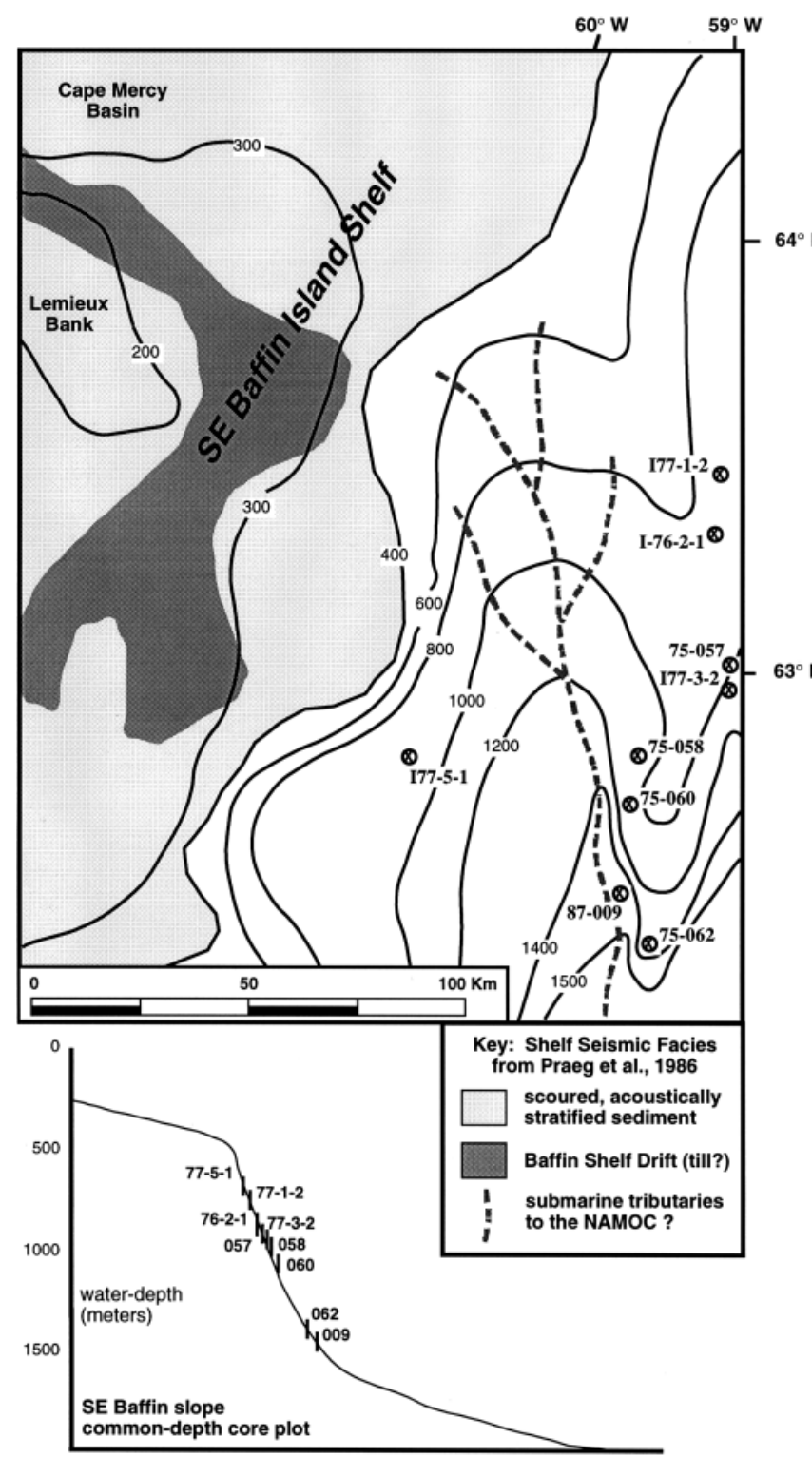

FIGURE 2. (Upper) Bathymetry (meters) and core locations (see Table I) off SE Baffin Island. Constructional seafloor morphology and acoustic signature indicates the extent of Baffin Shelf Drift on the shelf (Praeg et al., 1986). (Lower): Location of the cores on a common depth diagram.

En haut :Bathymétrie et localisation des carottes (voir tabl. I) au large du sud-est de l'île de Baffin. La morphologie du fond marin et la signature acoustique donnent l'extension de la dérive de la plateforme de Baffin (Praeg et al., 1986). En bas : Localisation des carottes sur la courbe des profondeurs.

and $\mathrm{H}$ - events? 3) are the DC-events on the shelf and slope the result of glacial discharge from Hudson Strait, Cumberland Sound, or Baffin Bay? and 4) what is the nature of sedimentation on this shelf/slope system; in particular, how dominant is iceberg rafting during $\mathrm{DC} / \mathrm{H}$-events at these iceproximal sites?

\section{BACKGROUND}

\section{BATHYMETRY AND MARINE GEOLOGY}

The cores sampled sediments between 700 and $1600 \mathrm{~m}$ water depth (wd) (Table I, Fig. 2). In this area the slope is steep and is cut by a major "valley". Above about $500 \mathrm{~m}$ wd the seaward gradient lessens and the shelf has been scoured by icebergs (Pereira et al., 1988). Praeg et al. (1986), using airgun and Huntec high resolution seismic surveys, mapped the distribution of the "Baffin Shelf Drift" ( i.e. till?) and the location and thicknesses of moraine-like accumulations (see Fig. 2). The interpretation of these features was based on their topographic expression and seismic character (Praeg et al., 1986). Jennings et al. (1996) suggested that they might represent a 11 ka late glacial ice margin. No site surveys of the slope were undertaken during the 1975 Hudson or Imperial (1976/1977) surveys, hence we have very limited information on the acoustic nature of the sediment on the continental slope.

The study area lies north of the mapped extent of tributaries of the North Atlantic Mid-Ocean Channel (NAMOC) (Chough, 1978; Chough et al., 1987; Hesse et al., 1987, 1996; Hesse and Rakofsky, 1992) although the incision implied in the bathymetry of the slope (Fig. 2) may provide some link between processes on this slope and the NAMOC.

At present, the upper $200 \mathrm{~m}$ of water on the shelf is dominated by relatively fresh and cold $\left(-1^{\circ}\right.$ to $\left.1^{\circ} \mathrm{C}\right)$ water entrained within the southward flowing Baffinland Current. Further offshore, a branch of the warmer West Greenland Current $\left(2^{\circ}-6^{\circ} \mathrm{C}\right)$ turns west from Greenland and merges with the Baffinland Current. The slope is affected by a western boundary undercurrent which loops around the southern tip of Greenland, enters the Labrador Sea and flows southward along the SE Baffin and Labrador slopes (Aksu and Mudie, 1985; Hillaire-Marcel et al., 1994). Changes in ocean circulation during MIS 5 to 1 are important in controlling such factors as the rate of iceberg melting, sources of icebergs, and deep sea sediment transport.

\section{GLACIAL GEOLOGY}

Based on the absence of late or postglacial beaches along the outer shores of Cumberland Peninsula, the presence of "old" ( $\geq 40 \mathrm{ka}$ ) raised marine deposits, and the weathering of the uppermost major moraine systems, it was proposed (Birkeland, 1978; Dyke et al., 1982; Locke, 1986, 1987) that outer Cumberland Peninsula, and by inference Cumberland Sound, were not inundated by the Laurentide Ice Sheet, although there probably was extensive alpine glaciation. However, at the head of the Sound and along the SW coast, the region was heavily scoured by continental ice (Andrews and Miller, 1979; Andrews et al., 1985). Recent work on marine and lacustrine sediments at the NE tip of Cumberland Peninsula (Andrews et al., 1996a; Moore, 1996) indicates that deglaciation of Sunneshine Fiord occurred prior to $11.5 \mathrm{ka}$. In the marine faunas there were indications of an abrupt change in conditions between 11 and $10 \mathrm{ka}$, i.e. 
coeval with the Younger Dryas chronozone and Heinrich event $\mathrm{H}-\mathrm{O}$ and a proposed glacial event in Cumberland Sound (Andrews et al., 1995a; Jennings et al., 1996) .

\section{PALEOENVIRONMENTS OF THE SE BAFFIN ISLAND SHELF}

Aksu and Mudie (1985) described and interpreted I77-2-1 and 177-5-1 and the other Imperial cores used in our paper. Three lithofacies were distinguished by color, mineralogy, and texture. Lithofacies A consists of a yellowish-brown sediment, often laminated, and "The carbonate content of this facies is between 50 and $90 \%$. Detrital mineralogy and reworked palymorph assemblages suggest that OrdovicianSilurian limestones and dolomites are the main source for lithofacies A" (Aksu and Mudie, 1985, p. 540). Lithofacies A is a key marker - referred to as DC- events in core HU87-009 (Andrews et al., 1993, 1994a). DC-0, -1, and -2 were shown by radiocarbon dating to be the proximal parts of Heinrich layers in the North Atlantic (Andrews et al., 1995a; Bond et al., 1992; Bond and Lotti, 1995). Lithofacies B consists of olive gray mud and gravelly sandy mud and is interpreted as hemipelagic sediment. Finally, Lithofacies $C$ is black (5Y2/1 to 5 YR2/1) gravelly to sandy muds. It "contains much more smectite and kaolinite, and less calcite and dolomite in the clay fraction. ...it was probably deposited by ice rafting" (Aksu and Mudie, 1985, p. 540). The increase in kaolinite may be a tracer for the Cretaceous outcrop on the floor of Cumberland Sound (Jennings, 1989, 1993; Jennings et al., 1996). Later work suggested that there were two sources for DC-events in the region: the first is dominated by calcite and appears to have a source in Hudson Strait; the other is dominated by dolomite with potential sources in Cumberland Sound and/or Baffin Bay (Andrews, 1993; Andrews et al., 1989, 1994b, 1995a; Jennings, 1993).

Work on the slope, and deep-sea floor immediately east of Hudson Strait (Fig. 1) provides strong evidence for major glacial/ocean interactions in the form of thick sequences of detrital rich, carbonate sediments (DC-events, Andrews and Tedesco, 1992). It was shown that the shelf was deglaciated after $\mathrm{H}-1$ ( $\leq 14.5 \mathrm{ka})$ but that the ice readvanced onto the inner shelf during H-0 (10-11 ka; Andrews et al., 1991, 1995a).

\section{DATA AND METHODS}

Fillon (1985) and Aksu and Mudie (1985) provided sedimentological, isotopic, and paleontological data on HU75009-IV-058 (henceforth HU75-58), and on 177-1-2 and 177-52 respectively. The grain-size spectra of ice rafted detritus (IRD) have been examined in detail for the northern Labrador Sea and adjacent areas (Fillon and Full, 1984). We have extracted data from these publications by scanning in and using a program (FlexiTrace ${ }^{\mathrm{TM}}$ ) to digitize the data. Magnetic susceptibility was measured on the archive-halves of cores which were reasonably well preserved. We provide new sedimentological data on cores HU75-009-IV-057 (Kirby, 1996) and 177-3-2, but our major contribution is to add 43 radiocarbon dates, most of which were on planktic foraminifera
(Table I), (Kaufman and Williams, 1992; Manley and Jennings, 1996; Jennings et al., 1996). The dates are all reported with a 450 year reservoir correction, although it appears certain that this effect has varied during the last deglacial cycle (Bard et al., 1994). Several of the cores, which are now over 20 years old (Chough, 1978), have been heavily sampled.

\section{RESULTS}

We recognize two sets of cores: most cores have a MIS 2/3 record and a truncated MIS 1 interval (177-2-1, I76-2-1, HU75-058, 177-5-1, HU87-009 and the trigger weight core for HU75-057). The other cores have dates in the range of $\geq$ $30 \mathrm{ka}$ at the core tops (HU75-057, 177-3-2, and HU75-060). HU75-062 is probably associated with the first set of sites, but the two dates (Table I) are inverted, possibly because of labeling errors in either sampling or in storage. This core is not considered further.

\section{SEDIMENTATION RATES}

Average rates of sediment accumulation (SAR) can be derived for four cores which had continuous sedimentation from early MIS 1 into MIS 3 (Fig. 3). Least squares linear SAR's varied from ca. 20 to $40 \mathrm{~cm} / \mathrm{ky}$ but reached values of $230 \mathrm{~cm} / \mathrm{ky}$ during DC-2 in HU87-009 (Table I). These average SARs noted above are not particularly high for sites that may have been close to ice margins (Eyles et al., 1985), suggesting that for much of MIS 2 and 3 the ice sheet was not at the shelf edge. On Figure 3 we show where the $\mathrm{H}$-events should lie (Bond and Lotti, 1995) with respect to depth in our cores.

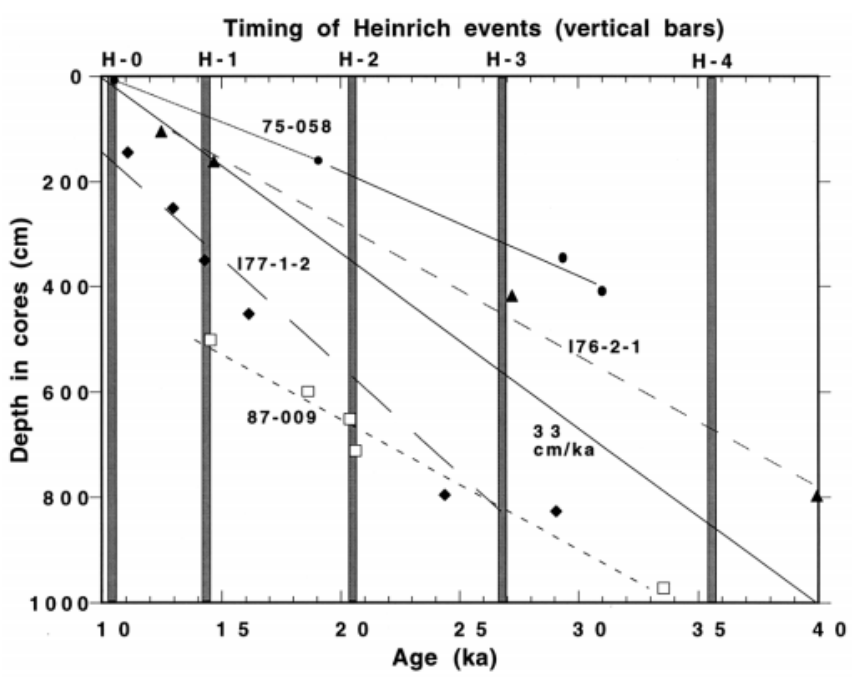

FIGURE 3. Depth/age curves for the cores with adequate radiocarbon dating control. The ages of the younger $\mathrm{H}$-events are shown as vertical shaded bars. For reference, the solid diagonal line represents a sedimentation rate of $33 \mathrm{~cm} / \mathrm{ka}$.

Courbes âges/profondeurs des carottes datés avec précision. Les épisodes de Heinrich sont identifiés par des barres verticales. La ligne diagonale continue représente un taux de sédimentation de 33 $\mathrm{cm} / \mathrm{ka}$. 
Dates from the tops of three piston cores are around 10 ka (Table I); the trigger weight (tw) core of HU87-009 has a date of $10,670 \pm 90$ (Table I) at $105 \mathrm{~cm}$, and the tw and pc sections can be matched from that depth to the top of both (Tedesco, 1993). Although some sediment was probably lost in the coring operations the results are similar to core top dates from the shelf east of Hudson Strait where sedimentation ceased about 8 ka once the LIS had retreated into Hudson Bay (Andrews et al., 1994b, 1995b). The abrupt decrease in the rate of sediment accumulation is due to sediment trapping in new basins within the continental margin (e.g. Cumberland Sound) (Andrews et al., 1994b; Jennings, 1993).

We present the core data in two segments: the first part deals with cores that have core top dates of $\leq 10 \mathrm{ka}$, whereas the second section deals with three cores whose core tops date from $\geq 30 \mathrm{ka}$.

\section{CORES WITH FINITE RADIOCARBON DATES}

1) HU75-058: there are data on grain-size, numbers of foraminifera, magnetic susceptibility, and $\partial^{18} \mathrm{O}$ of the leftcoiling (s) planktic foraminifera Neogloboquadrina pachyderma s. (Fig. 4) (Fillon, 1985; Fillon and Aksu, 1985). There is a strong positive correlation between the $>63 \mu \mathrm{m}$ (IRD) fraction and the numbers of foraminifera. Both parameters peak above and below zones which are essentially barren of foraminifera. A date of $18.7 \mathrm{ka}$ (Table I, Fig. 4) on N. pachyderma s. was obtained on a foraminiferal abundance peak at $\sim 160 \mathrm{~cm}$. Similar peaks above and below DC-events were noted by Jennings et al. (1996) in HU87-009. The foramineral barren zones are considered to represent DC-1 and DC2 respectively, and there is a lower zone between 400 and
$500 \mathrm{~cm}$ with similar characteristics. Reversals in the ${ }^{14} \mathrm{C}$ dates (Table I) suggest some reworking; this is certainly true of a shell fragment from $175 \mathrm{~cm}$ but it most probably also applies to the date at $50 \mathrm{~cm}$.

No carbonate data are available from this heavily sampled core, but magnetic susceptibility data (Fig. 4) indicate that the lowermost event has consistently low MS. There is no obvious decrease in MS in the upper two zones as might be expected if the sediment had been strongly diluted with calcium carbonate (Andrews and Tedesco, 1992). The $\partial^{18} \mathrm{O}$ data do not show a strong association between DC-events and light isotopic values (Andrews et al., 1994a). In conclusion, HU75-058 exhibits three zones which have certain characteristics of Heinrich events (Bond et al., 1992; Heinrich, 1988; Ruddiman and Mclntyre, 1981), i.e. low foraminiferal numbers and $\partial^{18} \mathrm{O}$ values of $\leq 4 \%$, but they are finegrained and only one has a low magnetic susceptibility signal suggestive of a high detrital carbonate content (Fig. 4).

2) 176-2-1 has four radiocarbon dates which indicate sedimentation throughout MIS 2 and into MIS 3 (Table I, Fig. 5). The core description indicates the presence of several DCevents (lithofacies A, Aksu and Mudie, 1985). When these are plotted with respect to time (Fig. 5) it indicates DC-1/H-1 at ca. $14.7 \mathrm{ka}$, probably DC-2/H-2 ca. $21 \mathrm{ka}$, and then there are four relatively thin DC-strata between $>26$ and $<39.5$ ka. Given the date of $26.7 \mathrm{ka}$ at $418 \mathrm{~cm}$ it appears that $\mathrm{H}-3$ is not present, at least as a carbonate event, just as it is not obvious at HU87-009 (Jennings et al., 1996). Two intervals of lithofacies $\mathrm{C}$ are recorded near the top and bottom of this core (Fig. 5).

\section{HU75-009-IV-058}

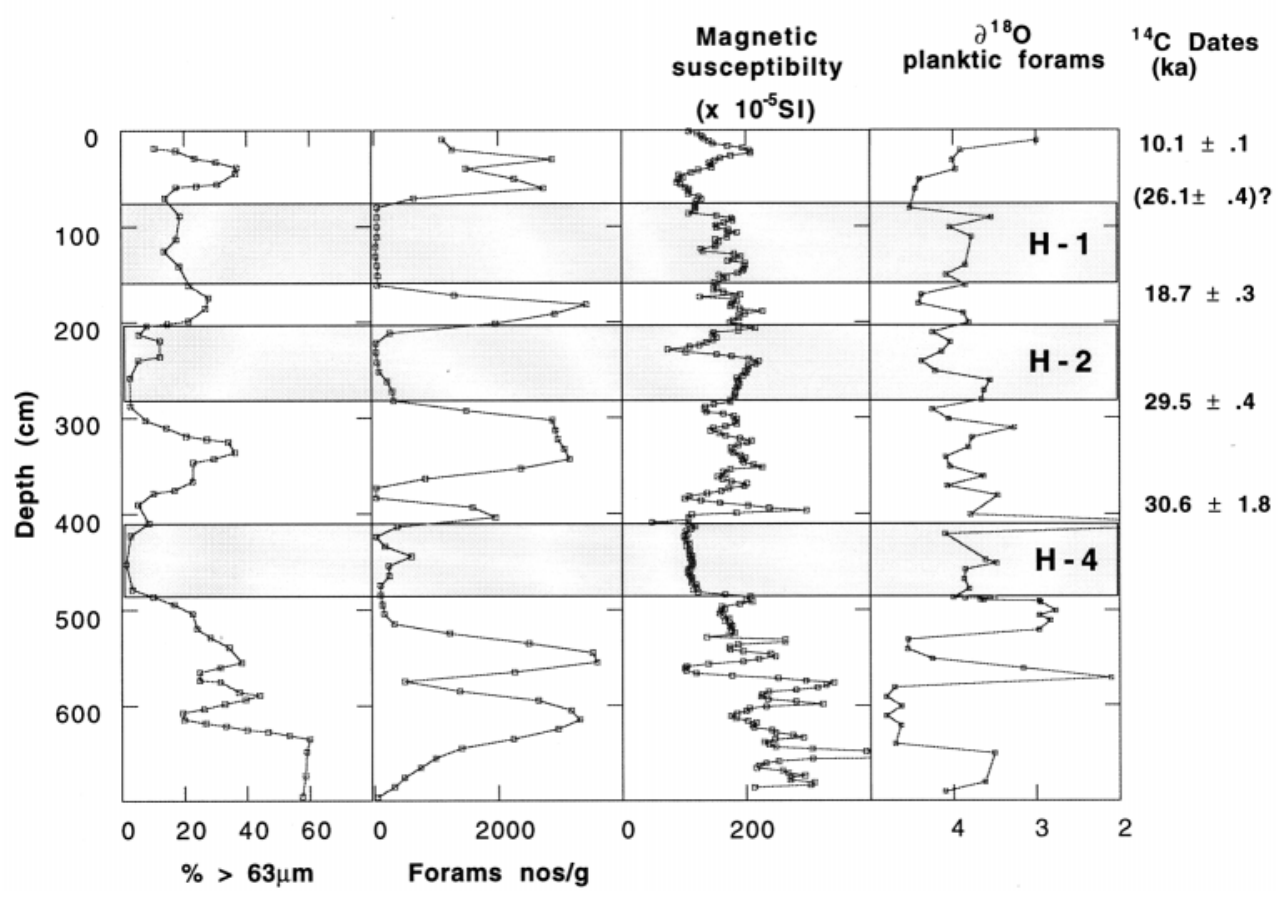

FIGURE 4. Data from HU75058 (see Fig. 2; cf. Fillon, 1985) with new AMS radiocarbon dates and magnetic susceptibility measurements.

Données de la carotte HU75-058 (voir la fig. 2; Fillon, 1985) avec les nouvelles dates AMS et les mesures de susceptibilité magnétique. 


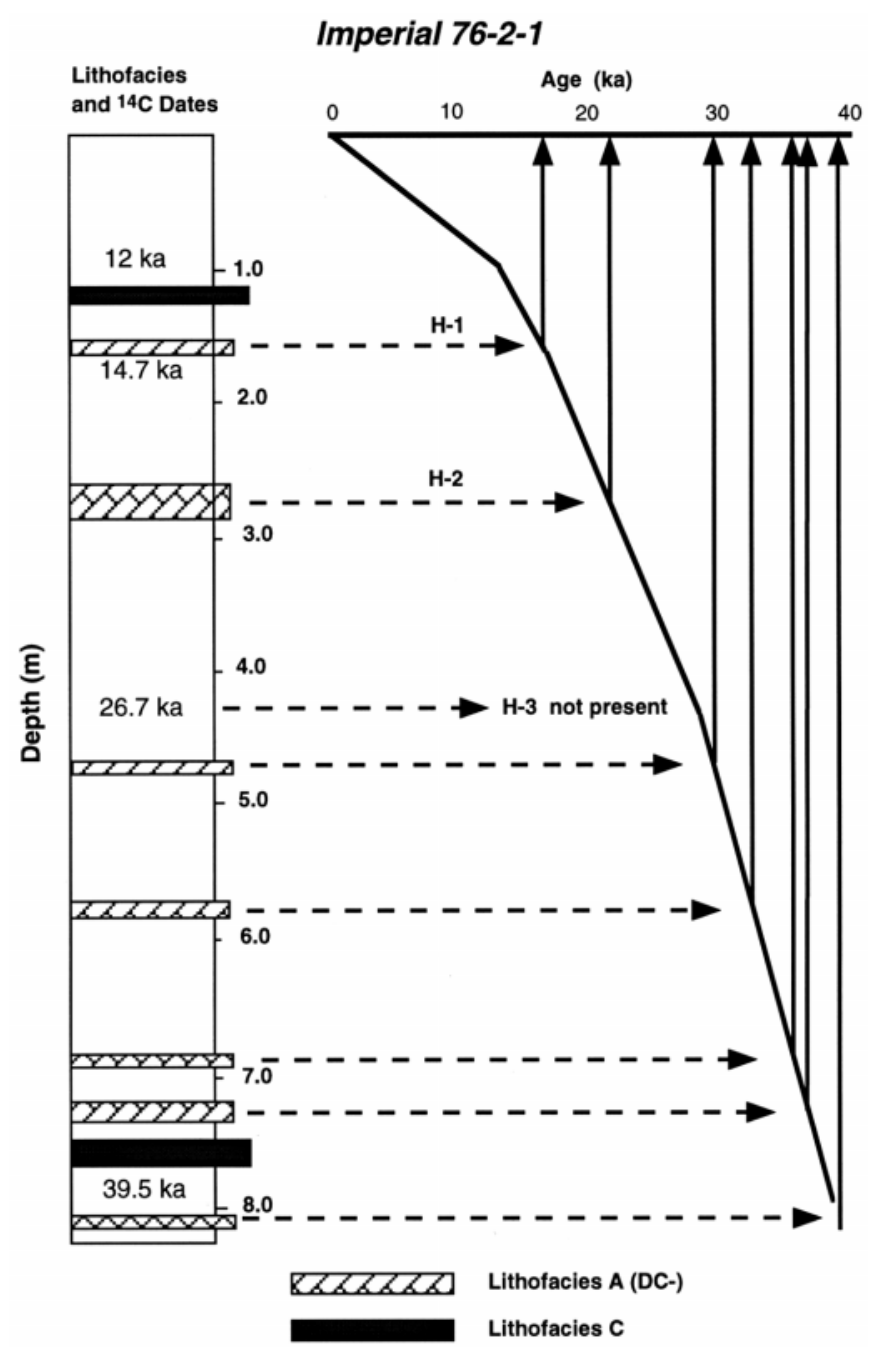

FIGURE 5. The column on the left shows $A M S{ }^{14} \mathrm{C}$ dates and the occurrence of lithofacies A (DC-layers) and C in 176-2-1 (from Aksu and Mudie, 1985). On the right is a depth/age curve to which the depth/age of the DC-events are related (lines with arrows). Notice the absence of a DC-event corresponding with $\mathrm{H}-3$.

La colonne de gauche donnent les dates $A M S$ au ${ }^{14} \mathrm{C}$ et les manifestations des lithofaciès $A$ (couches $C D$ ) et $C$ dans la carotte 176-2-1 (de Aksu et Mudie, 1985). À droite, courbe âges-profondeurs à laquelle sont reliés les épisodes CD (flèches). Noter l'absence de correspondance avec $\mathrm{H}$-3.

3) 177-1-2: Six AMS ${ }^{14} \mathrm{C}$ dates delimit the chronology. A DC-event is shown on the log description at $\sim 620 \mathrm{~cm}$ (Aksu and Mudie, 1985) which probably represents $\mathrm{H}-2$, based on the bracketing ${ }^{14} \mathrm{C}$ dates (Fig. 6). The core bottoms in carbonate rich gravelly mud dated $>29 \mathrm{ka}(\mathrm{H}-4$ ? $)$. There is no obvious representative of $\mathrm{H}-1$ in this core. Two intervals of lithofacies $\mathrm{C}$ occur between 4 and $6 \mathrm{~m}$ core depth. The $\partial^{18} \mathrm{O}$ record of this core shows a "classic" glacial/deglacial meltwater pulse dated close to $14 \mathrm{ka}$, approximately coincident with $\mathrm{H}-1$ (Andrews et al., 1994a). However, there is no simple relationship between the fraction of the sediment $>63 \mu \mathrm{m}$ and $\mathrm{H}$-events. During the LGM, hemipelagic deposition at this site resulted in $<10 \%$ sand by weight, and the numbers

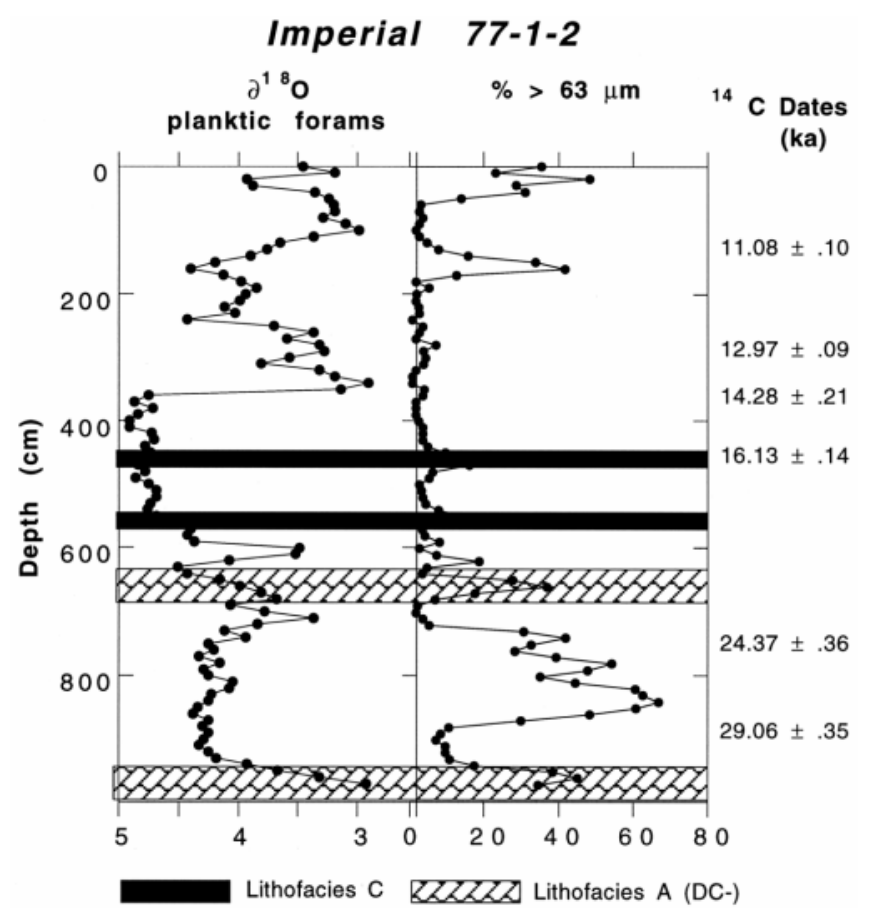

FIGURE 6. Variations in $\partial^{18} \mathrm{O}$ of near-surface planktic foraminifera and changes in the sand content of 177-1-2 (Aksu and Mudie, 1985). Variations $d u \partial^{18} \mathrm{O}$ des foraminifères planctoniques de surface et changements dans la teneur de sable de la carotte 177-1-2 (Aksu et Mudie, 1985).

of foraminifera/g were $>1000$ (Aksu and Mudie, 1985, p. 543) (Fig. 6).

4) $177-5-1$ is now missing and we have only been able to obtain one AMS date (Table I) which, however, was argued to be incorrect, based on the $\partial^{18} \mathrm{O}$ record (Andrews et al., 1994a). $177-5-1$ is located closer to the shelf break than other cores (Fig. 2) and it is noteworthy that this core has three DC-events, and seven dark lithofacies $\mathrm{C}$ episodes (Fig. 7) (Aksu and Mudie, 1985). Based on the correlation between 177-1-2 and 177-5-1 (Fig. 6) (Andrews et al., 1994a), it appears that $\mathrm{H}-1,-2$ and $\mathrm{H}-4$ are present in $177-5-1$ but only $\mathrm{H}-2$ is present as a DC-event in 177-1-2 (Fig. 7). Deposition of lithofacies $\mathrm{C}$ occurred immediately after $\mathrm{H}-4$ and $\mathrm{H}-1$.

5) HU87-009 has been studied extensively (Andrews et al., 1994a; Hillaire-Marcel et al., 1994; Jennings et al., 1996); further studies are ongoing (Barber et al., 1996). This core is located toward the base of the slope on a conspicuous "drift". The core contains three DC-events below $4.5 \mathrm{~m}$ core depth; two correlate with $\mathrm{H}-1$ and $\mathrm{H}-2$, whereas the lowermost event is dated as significantly older than $\mathrm{H}-3$, thus it may be H-4 (Jennings et al., 1996). There is a small, but distinct intermediate DC-event between DC- 1 and -2 , which has also been observed in cores from east of Hudson Strait in the Labrador Sea (Hillaire-Marcel and de Vernal., 1989). It is associated with a light isotope event in near-surface planktic foraminifera dated close to 16.8 ka (Andrews et al., 1994a). 


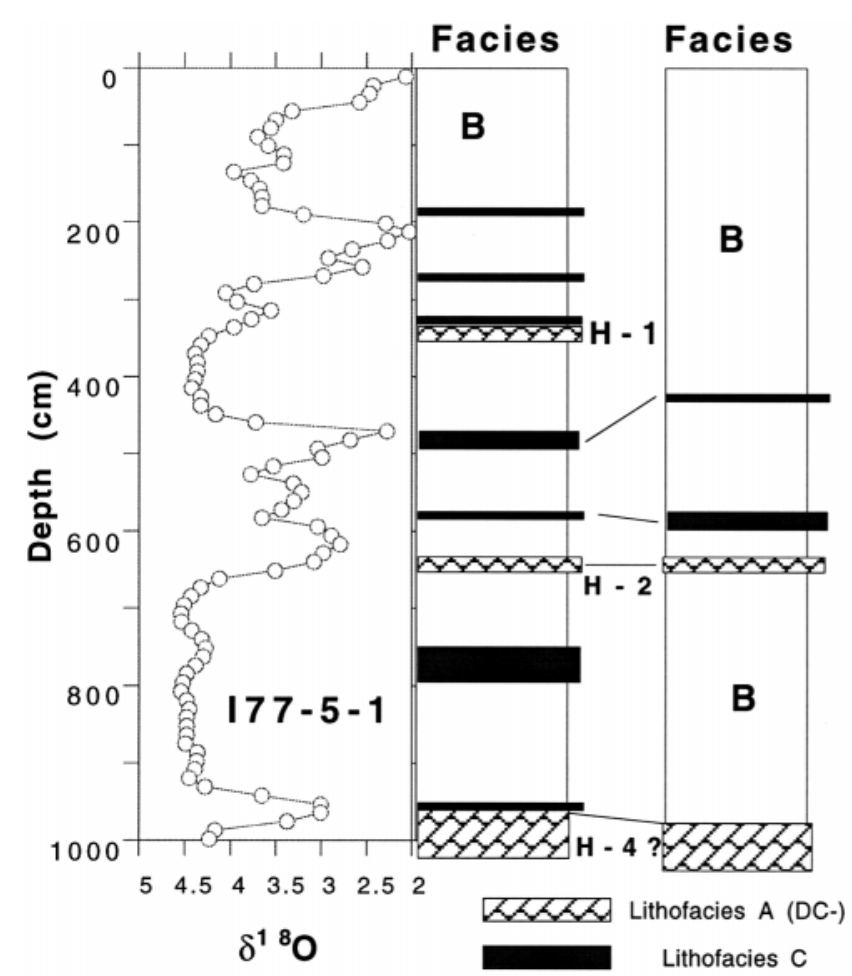

Jennings et al. (1996) interpreted the presence of dolomite peaks, dark grey and black sediments (i.e. Lithofacies C), and shallow water benthic foraminifera in this core as recording two intervals of ice advance from Cumberland Sound onto the shelf. The older event occurs just above the 34 ka date (Table I) whereas the last event is coeval with the Younger Dryas/H-O event.

\section{CORES WITH INFINITE RADIOCARBON DATES}

Because we do not have seismic control along this section of the slope an explanation for these older sediments outcropping on the surface is unknown. We suspect that sediment gravity flows may have resulted in the removal of the uppermost MIS 1 and 2 sediments.

6) 177-3-2 is one of three cores which have core top dates $\geq 30 \mathrm{ka}$. This core has a date at $105 \mathrm{~cm}$ of $35.57 \pm 0.8 \mathrm{ka}$ and $41.35 \pm 1.7 \mathrm{ka}$ at $305 \mathrm{~cm}$ (Fig. 8A). All of the dates may be minimum ages. There is a positive correlation between the lithofacies identification (Aksu and Mudie, 1985) and the results of grain-size and mineralogical analyses (Fig. 8A). There are at least five discrete DC-events in the upper $5 \mathrm{~m}$ (below $600 \mathrm{~cm}$ the core was not well preserved). Three of the DC-events (lithofacies A) have a ratio of calcite/dolomite >1.0. In all five DC-events the weight percentage of total carbonate is between 30 and $60 \%$, a higher proportion than in the DC intervals of HU75-057 (Fig. 8C).

7) HU75-060. Although the dates are reversed we believe that this is a function of sample size, i.e. smaller samples result in "younger" ages (Table I). Chough (1978) provides a lithofacies log for this core. Based on the style of sedimentation he indicates it is from a "channel-fill position". Most of

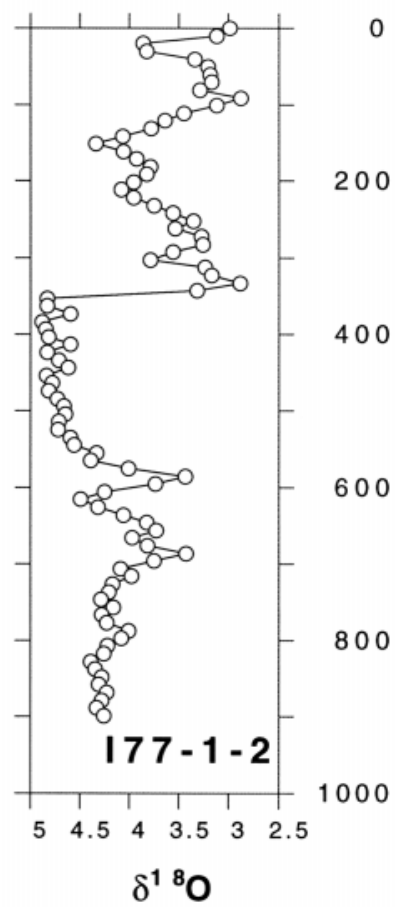

FIGURE 7. Variations in the $\partial^{18} \mathrm{O}$ of near-surface planktic foraminifera and location of lithofacies (from Aksu and Mudie, 1985) from 177-5-1 and 177-1-2 (see Fig. 2)

Variations $d u \quad \partial^{18} \mathrm{O}$ des foraminifères planctoniques de surface et localisation des lithofaciès (Aksu et Mudie, 1985) des carottes 177-5-1 et 177-1-2 (voir la fig. 2)

the core is hemipelagic sediment (lithofacies B) with scattered IRD, but there are discrete intervals that Chough (1978) recorded as "massive fine to medium sand" that may coincide with $\mathrm{DC} / \mathrm{H}$-events. The magnetic susceptibility log (Fig. 8B) suggests significant variability in sediment grainsize and/or mineralogy. Intervals of low magnetic susceptibility coincide with intervals of increased sand and, based on previous studies (Andrews et al., 1994b), imply that these episodes are also ones of increased detrital carbonate input. Thus HU75-060 records possibly four (4) DC-events; the first occurred sometime before $43.2 \mathrm{ka}$ (Fig. 8B).

8) HU75-057 is from $1 \mathrm{~km}$ water depth (Fig. 2) and consists of trigger(tw) and piston cores (Kirby, 1996). We investigated the importance of sample size on AMS ${ }^{14} \mathrm{C}$ dating, by obtaining dates from different sample weights at the base of the trigger core (Kirby, 1996; Manley and Jennings, 1996) (Table I ). Results indicate that for dates $\geq 20 \mathrm{ka}$, sample size is critical (the University of Arizona AMS Facility are developing methods to compensate for small sample effects, T. Jull, pers. commun. 1996).

There is a gap of $\sim 13$ ky between the base of the tw and the top of the piston core (Fig. 8C); this gap could either indicate that erosion of sediment occurred prior to $19 \mathrm{ka}$ or that the piston core bypassed sediment. Given the distribution (Fig. 2) of sites with "old" dates it is more likely that the former explanation applies, but this cannot be proven.

The basal trigger weight date of $19.12 \pm 16$ comes from a zone with high abundance of planktic foraminifera. Jennings et al. (1996) noted that peaks of foraminifera occurred at the onset and termination of DC-events in HU87-009, and continued into each event. We believe that the base of the tw 
A) $177-3-2$
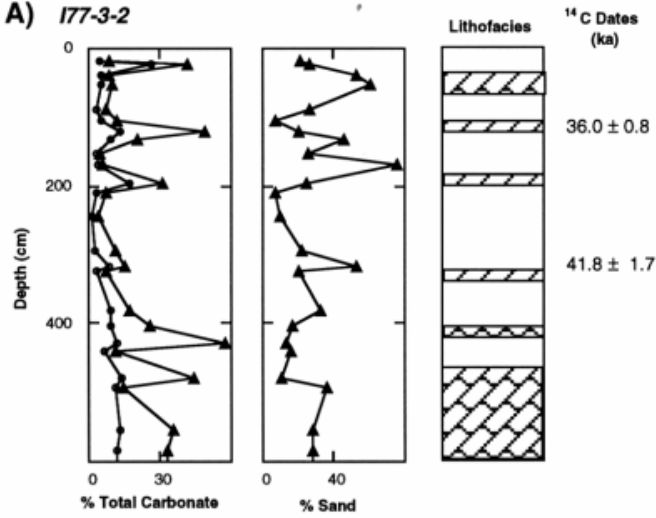

B)

B) HU75-060
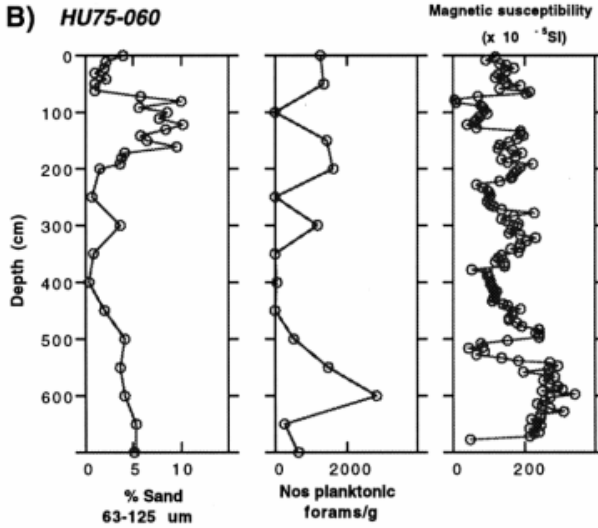

$\left(\times 10^{-3} \mathrm{sin}\right)$

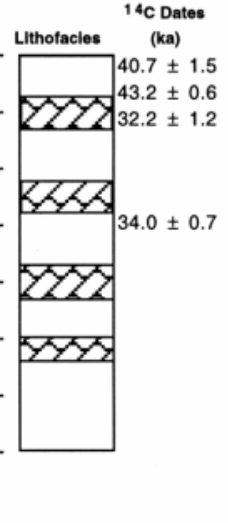

C) HU75-057

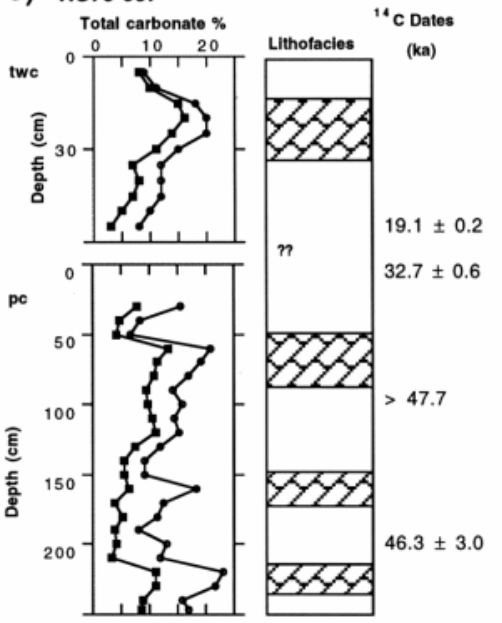

FIGURE 8. A: 177-3-2. Changes in carbonate (outer line total carbonate \%, inner dolomite \%) and sand content compared with lithofacies and radiocarbon dates. B: HU75-060. Changes in sand content, numbers of foraminifera/g (Fillon, unpubl. data), and archive-half magnetic susceptibility (x 10-5 SI). C: HU75-057. Changes in carbonate content (outer line total carbonate \%, inner dolomite \%), lithofacies (Aksu and Mudie, 1985) and radiocarbon dates.

A) 177-3-2, Changements dans les teneurs de carbonate (ligne externe, \% de carbonate total, ligne interne, \% de dolomite) et de sable en rapport avec les lithofaciès et les dates au radiocarbone. B) HU75-060. Changements dans la teneur en sable, dans le nombre de foraminifères/g (Fillon, non publié) et la susceptibilité magnétique (x $\left.10^{-5} \mathrm{SI}\right)$. C) HU75-057. Changements dans la teneur de carbonate (ligne externe, \% de carbonate total, ligne interne, \% de dolomite), les lithofaciès (Aksu et Mudie, 1985), et les dates au radiocarbone. core HU75-057 ends close to the top of $\mathrm{H}-2$. There is a 15 $\mathrm{cm} \mathrm{DC-event} \mathrm{at} 20 \mathrm{~cm}$ in the tw core which probably correlates with DC-1 at $14.5 \mathrm{ka}$. In the piston core, carbonate analysis indicates that $\sim$ three DC-events date $>32.7 \mathrm{ka}$. However, total carbonate is never more that $25 \%$ by weight which is significantly less than in cores HU75-55, HU75-56, and HU87-009.

\section{DISCUSSION}

Sediment layers with high detrital carbonate are common in cores from the slope of SE Baffin Island. These cores are located north of the major LIS outlet through Hudson Strait (Boulton and Clark, 1990; Fisher et al., 1985; Hughes, 1987; Marshall and Clarke, 1996) (Fig. 1) and north of the major NAMOC tributary systems (Hesse and Rakofsky, 1992). This section of the slope (Figs. 1 and 2) lies immediately below the area where ice from Cumberland Sound extended onto the shelf (Jennings, 1993; Jennings et al., 1996).

Figure 9 is a correlation diagram for the cores in which we have used our various proxies and measurements to locate $\mathrm{DC} / \mathrm{H}$-events. $\mathrm{H}-1,-2$, and -4 occur in many of the cores but $\mathrm{H}-3$ is apparently absent. Several (3 - 4) DC- events occur beyond the reliable application of radiocarbon dates (say $\geq 40$ ka). However, if SAR is similar to that recorded in some cores (Fig. 3) (20-40 cm/ky), then HU75-057 and -060, and 177-3-2 must extend the record of DC-events back into early MIS3 and MIS4, i.e. ca. 40 to $80 \mathrm{ka}$.

The occurrence of lithofacies $C$ (Figs. 5, 6 and 7) is most frequent in 177-5-1, the core closest to the shelf break (Fig. 2). Evidence from 177-5-1 and 176-2-1 indicates that lithofacies $\mathrm{C}$ occurs after DC-1/H-1. In 177-5-1 and I77-1-2 there appear to be two coeval occurrences between DC-1 and DC-2 (=lithofacies A) (Fig. 7), and in I77-5-1 and I76-2-1 there is a major unit of lithofacies $C$ toward the base of both cores. There is a suggestion in 177-5-1 and I76-2-1 that lithofacies $C$ occurs shortly after deposition of lithofacies $A$ (a DC-event).

\section{DEPOSITIONAL PROCESSES - SOURCES AND ENVIRONMENTS}

In retrospect, Chough (1978) and Aksu and Mudie (1985) described the proximal equivalents to "Heinrich" events prior to Heinrich's 1988 publication, but these studies occurred prior to reliable ${ }^{14} \mathrm{C}$ dating of glacial marine, clastic-dominated sediments, and the interest in their association with abrupt glaciological change (Alley, 1995; Alley and MacAyeal, 1994; MacAyeal, 1993) was not realized.

The literature on Heinrich $(\mathrm{H}-)$ events is dominated by the importance of the iceberg rafting process (IRD) for the emplacement of sand-sized lithic fragments thousands of kilometers from continental margins (e.g. Bond and Lotti, 1995; Dowdeswell et al., 1995; Heinrich, 1988). However, sedimentary processes on glaciated continental margins are far more complicated that just the release of sediments from icebergs (Hesse, 1992; Hesse and Khodabakhsh, 1995; Warren, 1992; Yoon et al., 1991). Some glaciated margins indicate the progradation of the slope by debris flows, such 
as the Bear Island Trough Fan (Vorren et al., 1988a, 1988b); by contrast, the slope off the northeastern North American margin is predominantly an erosive environment tied to the NAMOC system with sediment transported by turbidity currents (Chough et al., 1987; Hesse et al., 1987, 1990). In addition, Hesse and Khodabakhsh (1995) proposed that substantial deposition of silts and clays within $\mathrm{H}$-layers occurred from nepheloid layers. Kennett (1982, p. 527) observed that although the primary source for nepheloid sediment is erosion of the seabed by deep-sea currents, other mechanics include "..the injection of fine material by turbidity currents, fine sediments moving down submarine canyons, and glacial flour being directly injected in the bottom waters ..." A complimentary model derives from recent work in East Greenland where iceberg melting resulted in an intermediate "nepheloid" layer at 100-400 m water depth (Syvitski et al., 1996). Other sources for high concentrations of suspended particulates are possible in the vicinity of active ice sheet margins.

We have obtained grain-size spectra from 177-3-2 and HU87-009 using sieving for the sand-size fraction and the "Sedigraph" for the fraction $<63 \mu \mathrm{m}$. These two cores span a depth range of $500 \mathrm{~m}$ wd (Fig. 2). DC-events (lithofacies A) and the intervening hemipelagic sediments (lithofacies B) are represented by several samples per facies. Figure 10 shows the resulting grain-size spectra for the matrix $(<2$ $\mathrm{mm}$ ) in DC-events and for the intervening hemipelagic sediments. In a simple model, parallel with data from more "southern" latitudes in the North Atlantic, we would predict that $\mathrm{H}$-events are characterized by an increase in the sandsize fraction, and moreover, that this fraction would be pri- marily unsorted. In the case of HU87-009 we used the interval at and below DC-1 into sediments of DC-3 (probably H-4, see earlier). Visually there is no obvious difference between the facies in HU87-009; both lithofacies have relatively low sand contents and have a peak in the medium to fine silt, with a large fraction $\geq 11$ phi $(20-50 \%$ by weight) (Fig. 10A and B). By contrast, the data from 177-3-2 (Fig. 10C and 10D) indicate that the DC-events are sandier than those in HU87-009; the hemipelagic intervals are mainly characterized by peaks in the fine sand and coarse silt fraction. However, most of the sediments in both cores are still texturally silty clays or clayey silts with large fractions 11 phi.

The occurrence of fine-grained sediments within the DCintervals is supported by visual inspection of $\mathrm{X}$-radiographs which frequently show that these events are composed of fine-grained, laminated sediments, with IRD clasts scattered throughout. Kirby (1996) interpreted the DC-sediments as probably representing distal turbidites (cf. Hesse and Khodabakhsh, 1995). Chough (1978) also had noted a variety of facies associated with turbidite deposition. They could also represent deposition of suspended sediment from extensive meltwater plumes. Despite our concentration on the origin and significance of lithofacies A and C (Figs. 5,6 and 7), it is emphasized that the greatest thickness of sediment cored belongs to lithofacies $\mathrm{B}$. This facies represents hemipelagic sedimentation with ongoing IRD deposition (i.e. not too different from present conditions). Thus over the total length of our record (e.g. Fig. 9) the slope off Cumberland Sound has been affected by deposition from adjacent glacial margins $\leq 20 \%$ of the time.

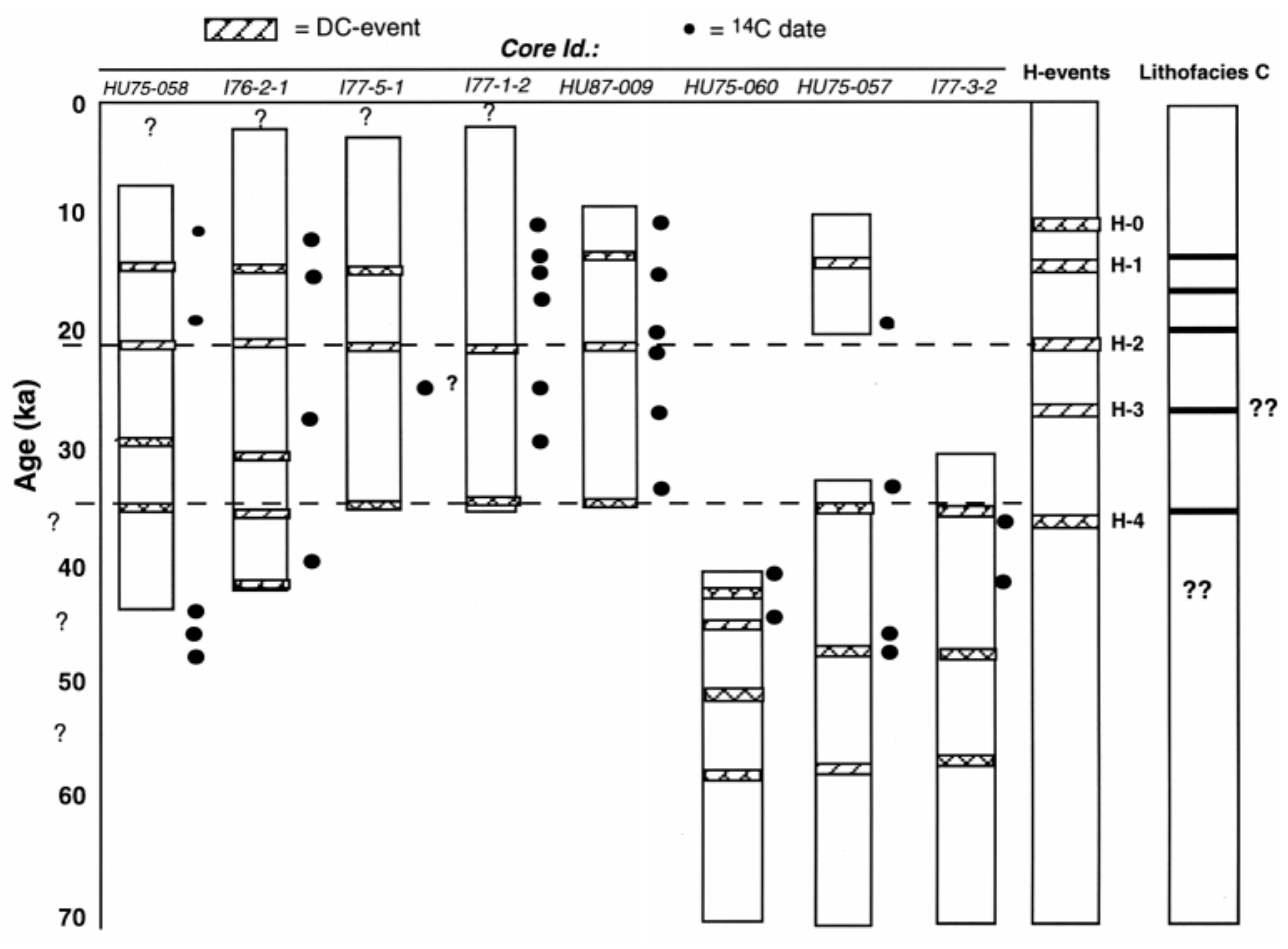

FIGURE 9. Chronostratigraphic occurrence of lithofacies A (DCevents) in the cores and possible correlations between the cores. The timing of $\mathrm{H}$-events and occurrences of lithofacies $\mathrm{C}$ are plotted to the right.

Chronostratigraphie des manifestations du lithofaciès $A$ (épisodes $C D$ ) dans les carottes et corrélations possibles entre les carottes. $\dot{A}$ droite, les manifestations d'épisodes $\mathrm{H}$ et du lithofaciès $C$. 
FIGURE 10. Grain-size spectra for DC-layers and intervening sediments from HU87-009 and 177-3-2.

Spectres granulométriques des couches $C D$ et des sédiments intermédiaires de HU87-009 et 177-3-2.
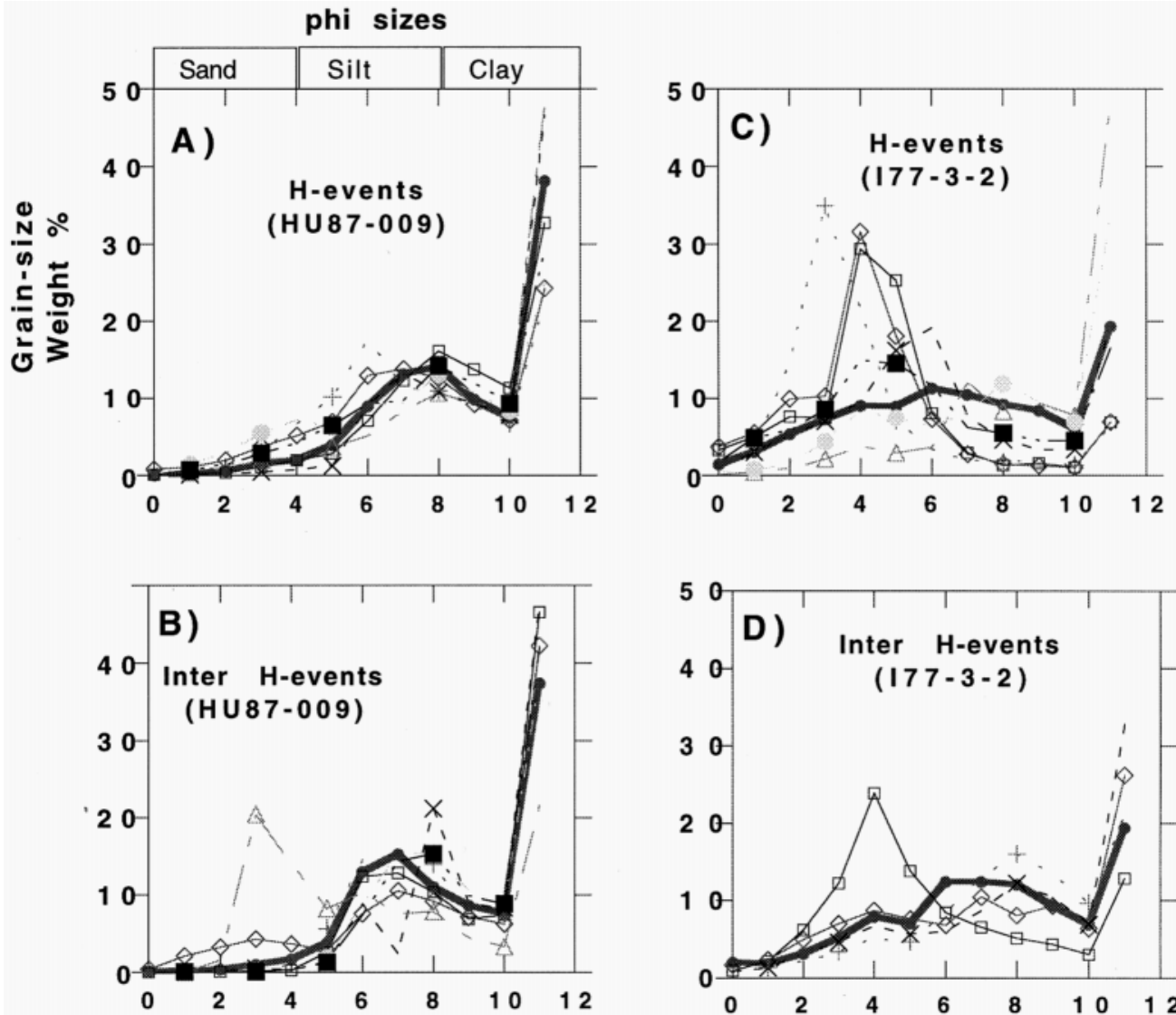

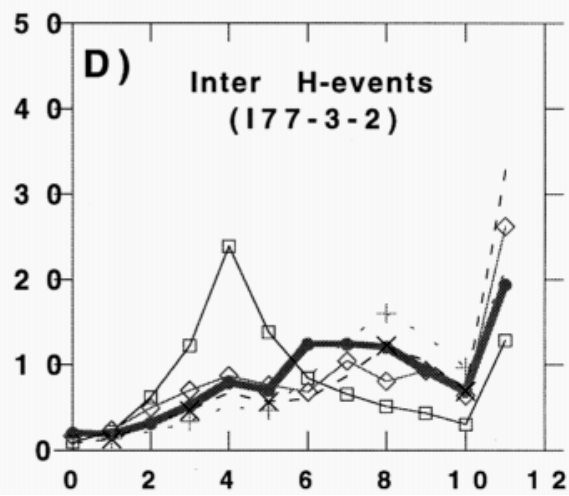

The most probable source of lithofacies $C$ (Fig. 9) is erosion of Cretaceous shales from the deep basin of Cumberland Sound (Jennings, 1993) (Fig. 1). However, not enough comparative research has been undertaken on this lithofacies to totally exclude other source areas, or possible recycling of sediment. For example, Jennings et al. (1996) inferred two episodes of shelf erosion from HU87-009 based on sediment color (dark) and benthic foraminiferal assemblages (Fig. 9)

The detrital carbonate that characterizes the DC- (lithofacies A) sediments could originate from: i) distal sedimentation from an ice stream source located in Hudson Strait and on the adjacent shelf, ii) ice flowing out of Cumberland Sound and eroding the Paleozoic outlier on the shelf off Cumberland Sound (MacLean, 1985), or iii) far travelled detrital carbonate carried by icebergs and suspended sediment from the Paleozoic Basins of NW Greenland and the High Canadian Arctic (Aksu, 1981; Krank, 1966; Marlowe, 1966). In Baffin Bay, the latter source is characterized by a high fraction of dolomite (Andrews, 1993; Andrews et al., 1989). A.S. Dyke (pers. commun. 1997) has noted that tills on Devon Island (at the head of the bay) have a mixture of both calcite and dolomite. The dominance of dolomite in Baffin Bay Quaternary sediments might be associated with either glacial erosion (if the spatial outcrop of dolomite greatly exceeds calcite-rich limestones), or it might reflect preferential dissolution of calcite (Aksu, 1983) during deposition. Thus we believe that a far "northern" source can largely be excluded on these grounds; plus data from Baffin Bay indicate that DC-sediments thin southward toward the Davis Strait (Andrews et al., 1996a). The Paleozoic bedrock within Cumberland Sound also has a high dolomite content (Jennings, 1989), however, analysis of three samples of bedrock carbonate, obtained by drilling from the Cumberland Sound/ Frobisher Bay Shelf (Fig. 1), resulted in calcite values of $\sim 40-95 \%$ by weight - the dolomite\% increased southward and ratios calcite/dolomite ratios of $\sim 1: 1$ occurred NE of Frobisher Bay (Kirby, 1996, Fig. 45).

On Figure 11 we plot total carbonate percentage versus the calcite/dolomite ratio for two cores. The plot is divided into four quadrants based on the medians. DC-events are noteworthy for carbonate values $\geq 25 \%$ and calcite/dolomite ratios $>1$. However, in the intervening hemipelagic intervals the calcite/dolomite ratios are $<1$. This change in the ratio might reflect an increase in the effectiveness of dissolution of the more reactive calcite during these periods (de Vernal et al., 1992; Jennings et al., 1996). There is a statistically significant relationship between total carbonate content and the calcite/dolomite ratio in two of the cores (Fig. 11).

Although the grounded ice margin on the shelf east of Hudson Strait generated turbidites during $\mathrm{H}$-events, it is improbable that turbidites from this locale could have reached our site (Fig. 1) and specifically influenced deposition across the $700 \mathrm{~m}$ depth transect (Fig. 2). Dowdeswell et al. (1995) mapped the thickness of $\mathrm{H}-1$ and $\mathrm{H}-2$ across the 


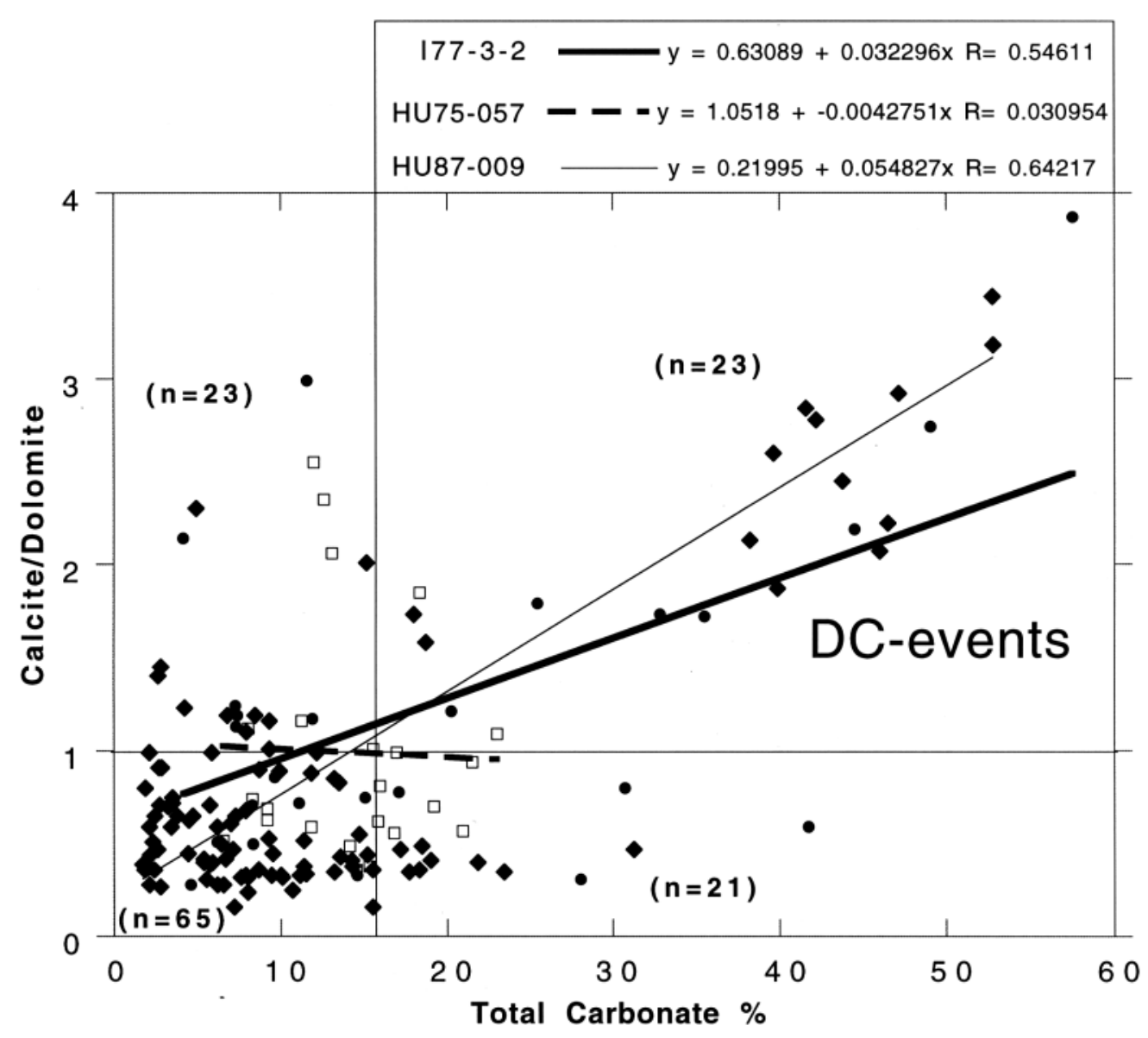

FIGURE 11. Total carbonate content from three cores plotted against the calcite/ dolomite ratio. The vertical line divides the data points into those with carbonate contents greater than and less than the median total carbonate content of ca. $15 \%$, and the horizonal line marks the $1: 1$ calcite/dolomite ratio. Sediments in DC layers plot in the upper right-hand quadrant. Regression lines for the cores are shown, although that for HU75-057 is not statistically significant.

Teneur en carbonate total de trois carottes sur le taux de calcite/dolomite. La ligne verticale sépare les points entre ceux dont la teneur en carbonate est plus grande ou moins grande que la teneur moyenne en carbonate total d'environ $15 \%$; la ligne horizontale représentel e taux de 1/1 de calcite/dolomite. Les lignes de régression des carottes sont représentées, bien que celle de HU75-057 ne soit pas statistiquement significative.

North Atlantic. On the scale of our study the thickness of $\mathrm{H}-1$ varies from absent (I77-1-2) to $70 \mathrm{~cm}$ (HU75-58), whereas $\mathrm{H}-2$ ranges between 20 and $90 \mathrm{~cm}$. Plots of the variations in DC-layer thickness (Fig. 12) indicate that lower values characterize the upper slope and that there is a tongue of thicker DC-sediments which may be restricted to the divides of a channel incised into the continental slope (Fig. 2). There is insufficient core and seismic coverage to comment in detail on these patterns of thickness except to note that the distribution of lithofacies A cannot be easily explained by downslope deposition from an ice margin grounded on the shelf and originating in Cumberland Sound. Two possible explanations of the isopach pattern are either transport of sediment northward from the Hudson Strait/ Hatton Basin shelf and slope, or significantly more accumulation on the "drift" because of selective preservation. As noted by Hesse and Khodabakhsh (1995), depositional processes of DC-/H- layers are complex, and we might add, not rigorously documented either spatially or temporally.

\section{CONCLUSIONS}

We are now in a position to answer as best we can our four introductory questions.

1) Can DC-events be correlated from core to core (Fig. 2)? The answer is "yes", although correlations beyond radiocarbon dates of ca. 35 ka have not been attempted (Fig. 9).

2) Are DC- layers equivalent to $\mathrm{H}$ - layers/events? The answer is "yes" for $\mathrm{H}-1, \mathrm{H}-2$, and probably $\mathrm{H}-4$; however, we conclude that there is no firm evidence for a detrital carbonate $\mathrm{H}-3$ event, north of Hudson Strait (Fig. 9). Note, however, that in core 176-2-1 there are several small DC events (Fig. $5)$, and there is a distinct intermediate DC-event in HU87009 between DC-1 and DC-2 (Jennings et al., 1996).

3) Are the DC-events on the shelf and slope the result of glacial discharge from Hudson Strait, Cumberland Sound, or Baffin Bay? We can probably exclude ice sheets north of Baffin Bay as a major source for DC-events on the SE slope of Baffin Island on the grounds of mineralogy and the pattern of DC-events within Baffin Bay (Andrews et al., 1996b). However, DC-0 at 11-10 ka may have a component associated with iceberg discharge from Baffin Bay (Andrews et al., 1996a). The large amount of calcite present in DC-events (Fig. 11) most likely represents a Hudson Strait source, although Kirby (1966) showed that the Paleozoic outcrop off Cumberland Sound (Fig. 1) is also high in calcite. The black color and mineralogy of lithofacies $C$ (Figs. 5 and 6) most probably represents erosion and transport of the Cretaceous mudstones which crop out on the floor of outer Cumberland Sound at $1200 \mathrm{~m}$ wd (Jennings, 1989, 1993) (Fig. 1). At two periods (Jennings et al., 1996), this lithofacies appears to 
FIGURE 12. Maps showing the variation in thickness of lithofacies $A$ (DC-layers) for $\mathrm{H}-1$ and $\mathrm{H}-2$ from cores on the SE Baffin slope; local thicknesses (cm) are given in bold. Water depth contours are in meters.

Cartes de la variation de I'épaisseur du lithofaciès $A$ (couches CD) au cours des épisodes de $\mathrm{H}$-1 et $\mathrm{H}$-2 à partir de carottes du talus continental du sud-est de Baffin ; les épaisseurs sont en gras. Les isobathes sont en mètres.

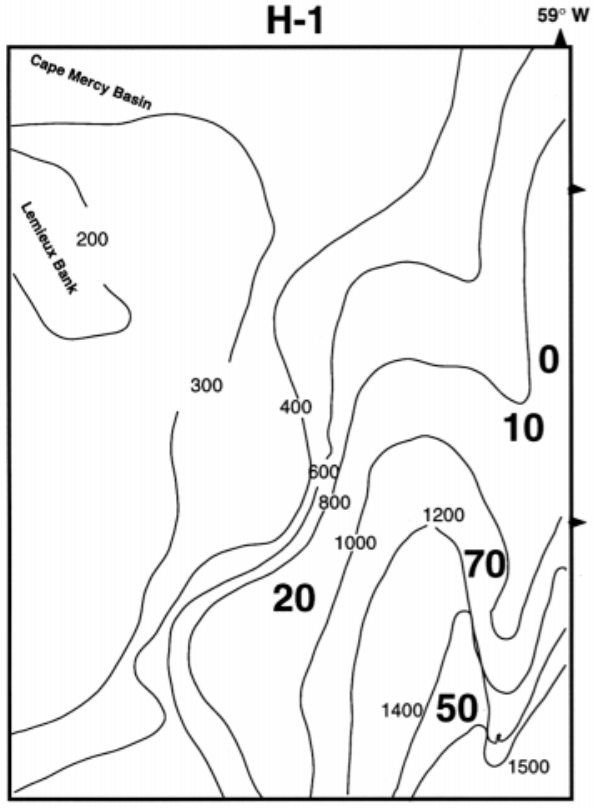

represent recycling of shelf sediments. The mapping of constructional glacial deposits on the shelf (Fig. 2) (Praeg et al., 1986) indicates that at some time(s), ice from Cumberland Sound expanded beyond the coastline to ground close to the shelf break; the last time this happened may have been close to $11 \mathrm{ka}$ (Fig. 9) (Jennings et al., 1996).

4) What is the nature of sedimentation on this shelf/slope system? On this slope system the dominant facies is silty clay with a variable IRD component (Fig. 10). The detrital carbonate (DC-) events are frequently fine-grained, have an erosional base, and are associated with deposition of turbidites generated at the ice margin (Hesse, 1992; Hesse et al., 1990, 1996; Kirby, 1996), but also reflect "rain-out" of finegrained particles from either overflow plumes or nepheloid layers (Hesse and Khodabakhsh, 1995). Furthermore, sediment gravity flows are an important element of both erosion and deposition in this area. Thus $\mathrm{H}$-events from ice-proximal slope sites are characterized by more complex sedimentary transport and depositional processes than ice-distal sites in the central and eastern North Atlantic where the dominant delivery process is iceberg rafting.

The identification of Heinrich layers in the North Atlantic marine sediment record has greatly increased our appreciation of the dynamics of large ice sheets and their importance to the climate system. However, the focus on their climatic correlations, lithic source materials, and spatial and temporal patterns has resulted in relatively little attention being paid to the issues of sediment transport and deposition, especially in ice-proximal slope and deep sea environments (cf. Hesse and Khodabakhsh, 1995). H-layers obviously reflect more than iceberg rafting. This paper has examined all the issues noted above and concludes that the issues of sediment transport and deposition are critical to a complete understanding of the glaciological and climatic importance of Heinrich events.

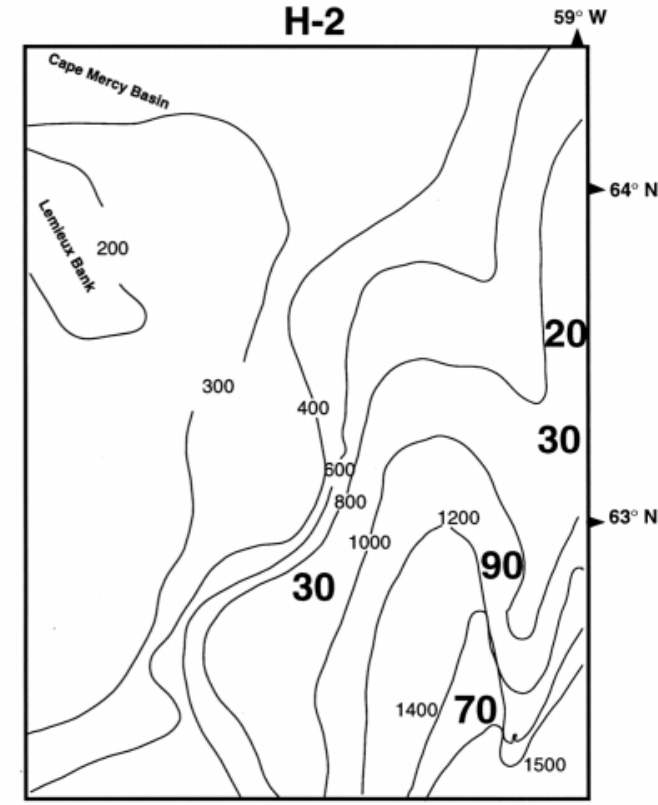

ACKNOWLEDGEMENTS

This research has been supported by a grant from the National Science Foundation, OPP-9321135 and NOAANA47GP0188. We are especially grateful to Iris Hardy and the Core Depository of the Bedford Institute of Oceanography, Canada, for access to materials. AMS radiocarbon dating has been mainly provided by the NSF Facility at the University of Arizona. We thank Drs. Ali Aksu and Alan R. Nelson for access to foraminiferal samples previously picked from the Imperial cores. We appreciate the constructive reviews provided by Drs. A. Dyke, R. Hesse, and S. Occhietti.

\section{REFERENCES}

Aksu, A.E., 1981. Late Quaternary stratigraphy, paleoenvironmentology, and sedimentation history of Baffin Bay and Davis Strait. PhD thesis, Dalhousie University, Halifax,771 p.

1983. Holocene and Pleistocene dissolution cycles in deep-sea cores of Baffin Bay and Davis Strait: Paleo-oceanographic implications. Marine Geology, 53: 331-348

Aksu, A.E. and Mudie, P.J., 1985. Late Quaternary stratigraphy and paleoecology of Northwest Labrador Sea. Marine Micropaleontology, 9: 537-557.

Alley, R.B., 1995. Resolved: The Arctic Controls Global Climate Change, p. 263-283. In Arctic Oceanography: Marginal Ice Zones and Continental Shelves Coastal and Estuarine Studies. American Geophysical Union.

Alley, R.B. and MacAyeal, D.R., 1994. Ice-rafted debris associated with bingepurge oscillations of the Laurentide Ice Sheet. Paleoceanography, 9: 503511.

Andrews, J.T., 1993. Changes in the silt- and clay-size mineralogy of sediments at ODP Site 645B, Baffin Bay. Canadian Journal of Earth Sciences, 30: 2448-2452.

Andrews, J.T., Geirsdottir, A. and Jennings, A.E., 1989. Spatial and temporal variations in clay- and silt-size mineralogies of shelf and fiord cores, Baffin Island. Continental Shelf Research, 9: 445-463. 
Andrews, J.T. and Miller, G.H., 1979. Glacial erosion and ice sheet divides, northeastern Laurentide Ice Sheet on the basis of limestone erratics. Geology , 7: 592-596.

Andrews, J.T. and Tedesco, K., 1992. Detrital carbonate-rich sediments, northwestern Labrador Sea: Implications for ice-sheet dynamics and iceberg rafting (Heinrich) events in the North Atlantic. Geology, 20: 10871090.

Andrews, J.T., Barber, D.C., Kirby M., Jennings, A.E. and Farmer, L., 1996b. Ice Sheet/Ocean interactions on millennium time-scales proximal to the Laurentide Ice Sheet: Labrador Sea and Baffin Bay 10 - $\geq 40$ ka. Abstract, no presentation, AGU Annual meeting. SF(Dec).

Andrews, J.T., Bond, G., Jennings, A.E., Kerwin, M., Kirby, M., MacLean, B., Manley, W. and Miller, G.H., 1995a. A Heinrich like-event, H-0 (DC-0): Source(s) for detrital carbonate in the North Atlantic during the Younger Dryas chronozone. Paleoceanography, 10: 943-952.

Andrews, J.T., Erlenkeuser, H., Evans, L., Briggs, W. and Jull, A.J.T., 1991. Meltwater and deglaciation SE Baffin Shelf (NE margin Laurentide Ice Sheet) between 13.5 and $8 \mathrm{ka}$ : From stable $\mathrm{O}$ and $\mathrm{C}$ data. Paleoceanography, 6: 621-637.

Andrews, J.T., Erlenkeuser, H., Tedesco, K., Aksu, A. and Jull, A.J.T., 1994a. Late Quaternary (Stage 2 and 3) meltwater and Heinrich events, NW Labrador Sea. Quaternary Research, 41: 26-34.

Andrews, J.T., MacLean, B., Kerwin, M., Manley, W., Jennings, A.E. and Hall, F., 1995b. Final stages in the collapse of the Laurentide Ice Sheet, Hudson Strait, Canada, NWT: Based on ${ }^{14} \mathrm{C}$ AMS dates, seismic stratigraphy and magnetic susceptibility logs. Quaternary Science Reviews, 14: 983-1004.

Andrews, J.T., Osterman, L.E., Jennings, A.E., Syvitski, J.P.M., Miller, G.H and Weiner, N., 1996a. Abrupt changes in marine conditions, Sunneshine Fiord, eastern Baffin Island, N.W.T. (ca. $66^{\circ} \mathrm{N}$ ) during the last deglacial transition: Links to the Younger Dryas cold-event and Heinrich, $\mathrm{H}-0$, p. 11 27. In J.T. Andrews, W. Austin, H. Bergsten and H.E. Jennings, eds., Late Quaternary Paleoceanography of North Atlantic Margins. Geological Society of London, London.

Andrews, J.T., Stravers, J.A. and Miller, G.H., 1985. Patterns of glacial erosion and deposition around Cumberland Sound, Frobisher Bay, and Hudson Strait, and the location of ice streams in the Eastern Canadian Arctic, p. 93117. In Models in Geomorphology. Allen and Unwin, Boston.

Andrews, J.T., Tedesco, K., Briggs, W.M. and Evans, L.W., 1994b. Sediments, sedimentation rates, and environments, SE Baffin Shelf and NW Labrador Sea 8 to 26 ka. Canadian Journal of Earth Sciences, 31: 90-103.

Andrews, J.T., Tedesco, K. and Jennings, A.E., 1993. Heinrich events: Chronology and processes, east-central Laurentide Ice Sheet and NW Labrador Sea, p. 167-186. In W.R. Peltier, ed., Ice in the Climate System. Springer-Verlag, Berlin Heidelberg.

Balkwill, H.R., McMillan, N.J., MacLean, B., Williams, G.L. and Srivastava, S.P., 1990. Geology of the Labrador Shelf, Baffin Bay, and Davis Strait, Chapter 7, p. 293-348. In M.J. Keen and G.L. Williams, eds., Geology of the Continental Margin of Eastern Canada. Geological Survey of Canada, Ottawa.

Barber, D.C., Andrews, J.T. and Jennings, A.E., 1996. Laurentide ice-flow during Heinrich events: $\mathrm{Nd}-\mathrm{Sr}-\mathrm{Pb}$ isotopic provenance. Abstracts, Geological Society of America Annual Meeting, Denver.

Bard, E., Arnold, M., Mangerud, J., Paterne, M., Labeyrie, L., Duprat, J., Melieres, M.-A., Sonstegaard, E. and Duplessy, J.-C., 1994. The North Atlantic atmosphere-sea surface ${ }^{14} \mathrm{C}$ gradient during the Younger Dryas climatic event. Earth and Planetary Science Letters, 126: 275-287.

Birkeland, P.W., 1978. Soil development as an indication of relative age of Quaternary deposits, Baffin Island, N.W.T., Canada. Arctic and Alpine Research, 10: 733-747.

Bond, G., Heinrich, H., Broecker, W.S., Labeyrie, L., McManus, J., Andrews, J.T., Huon, S., Jantschik, R., Clasen, S., Simet, C., Tedesco, K., Klas, M., Bonani, G. and Ivy, S., 1992. Evidence for massive discharges of icebergs into the glacial Northern Atlantic. Nature, 360: 245-249.

Bond, G.C. and Lotti, R., 1995. Iceberg discharges into the North Atlantic on millennial time scales during the last glaciation. Science, 267: 1005-1009.
Boulton, G.S. and Clark, C.D., 1990. The Laurentide ice sheet through the last glacial cycle: The topology of drift lineations as a key to the dynamic behaviour of former ice sheets. Transactions of the Royal Society of Edinburgh: Earth Sciences, 81: 327-347.

Broecker, W.S., Bond, G., McManus, J., Klas, M. and Clark, E., 1992. Origin of the Northern Atlantic's Heinrich events. Climatic Dynamics, 6: 265-273.

Chough, S.K., 1978. Morphology, sedimentary facies and processes of the Northwest Atlantic Mid-Ocean Channel between 61 and $52 \mathrm{~N}$, Labrador Sea. Ph.D. thesis, Department Geological Sciences, McGill University, Montreal, $167 \mathrm{p}$

Chough, S.K., Hesse, R. and Muller, J., 1987. The Northwest Atlantic MidOcean Channel of the Labrador Sea. IV. Petrography and provenance of the sediments. Canadian Journal of Earth Sciences, 24: 731-740.

de Vernal, A., Bilodeau, G., Hillaire-Marcel, C. and Kassou, N., 1992. Quantitative assessment of carbonate dissolution in marine sediments from foraminifer linings vs. shell ratios: Davis Strait, Northwest North Atlantic. Geology, 20: 527-530.

Denton, G.H. and Hughes, T.J., 1981. The Last Great Ice Sheets. John Wiley \& Sons, New York, $484 \mathrm{p}$.

Dowdeswell, J.A., Maslin, M.A., Andrews, J.T. and McCave, I.N., 1995. Iceberg production, debris rafting, and the extent and thickness of Heinrich layers $(\mathrm{H}-1, \mathrm{H}-2)$ in North Atlantic sediments. Geology, 23: 301-304.

Dyke, A.S., Andrews, J.T. and Miller, G.H., 1982. Quaternary geology of Cumberland Peninsula, Baffin Island, District of Franklin. Geological Survey of Canada Memoir 403, $32 \mathrm{p}$.

Eyles, C.H., Eyles, N. and Miall, A.D., 1985. Models of glaciomarine sedimentation and their application to the interpretation of ancient glacial sequences. Palaeogeography, Palaeoclimatology, Palaeoecology, 51: 1584.

Fillon, R.H., 1985. Northwest Labrador Sea stratigraphy, sand input and paleoceanography during the last 160,000 years, p. 181-209. In J.T. Andrews, ed., Quaternary Environments: Eastern Canadian Arctic, Baffin Bay and Western Greenland. Allen and Unwin, Boston.

Fillon, R.H. and Aksu, A. (eds.), 1985. Evidence for subpolar influence in the Labrador Sea and Baffin Bay during marine isotope stage 2, p. 248-262. In J.T. Andrews, ed., Quaternary Environments: Eastern Canadian Arctic, Baffin Bay and Western Greenland. Allen and Unwin, Boston.

Fillon, R.J. and Full, W.E., 1984. Grain size variations in North Atlantic noncarbonate sediments and sources of terrigenous components. Marine Geology, 59: 13-50.

Fisher, D.A., Reeh, N. and Langley, K., 1985. Objective reconstruction of the late Wisconsinan Laurentide Ice Sheet and the significance of deformable beds. Géographie physique et Quaternaire, 39: 229-238.

Fulton, R.J. (ed.), 1989. Quaternary Geology of Canada and Greenland. Geological Society of America, Boulder, 839 p.

Grousset, F.E., Labeyrie, L., Sinko, J.A., Cremer, M., Bond, G., Duprat, J., Cortijo, E. and Huon, S., 1993. Patterns of ice-rafted detritus in the glacial North Atlantic $\left(40-55^{\circ} \mathrm{N}\right)$. Paleoceanography, 8: 175-192.

Gwiazda, R.H., Hemming, S.R. and Broecker, W.S., 1996. Tracking the sources of icebergs with lead isotopes: The provenance of ice-rafted debris in Heinrich layer 2. Paleoceanography, 11 (1): 77-93.

Heinrich, H., 1988. Origin and consequences of cyclic ice rafting in the Northeast Atlantic Ocean during the past 130,000 years. Quaternary Research, 29: 143-152.

Hesse, R., 1992. Continental Slope Sedimentation adjacent to an Ice Margin. I. Seismic Facies of Labrador Slope. Geo-Marine Letters, 12: 189-199.

Hesse, R. and Khodabakhsh, S., 1995. Depositional mechanisms of Heinrich layers revealed by x-radiography and grain-size analysis. Abstract volume, 5th International Conference of Paleoceanography, Halifax, p. 97.

Hesse, R. and Rakofsky, A., 1992. Deep-sea Channel/Submarine-Yazoo system of the Labrador Sea: A new deep-water facies model. American Association of Petroleum Geologist Bulletin, 76: 680-707.

Hesse, R., Chough, S.K. and Rakofsky, A., 1987. The Northwest Atlantic MidOcean Channel of the Labrador Sea. V. Sedimentology of a giant deep-sea channel. Canadian Journal of Earth Sciences, 24: 1595-1624. 
Hesse, R., Klaucke, I., Ryan, W.B.F., Edwards, M.B., Piper, D.J.W. and NAMOC Study Group, 1996. Imaging Laurentide Ice Sheet Drainage into the Deep Sea: Impact on Sediments and Bottom Water. GSA Today, 6: 39.

Hesse, R., Rakofsky, A. and Chough, S.K., 1990. The central Labrador Sea: Facies and dispersal patterns of clastic sediments in a small ocean basin. Marine and Petroleum Geology, 7: 13-28.

Hillaire-Marcel, C. and de Vernal, A., 1989. Isotopic and palynological records of the late Pleistocene in Eastern Canada and adjacent ocean basins. Géographie physique et Quaternaire, 43: 263-290.

Hillaire-Marcel, C., de Vernal, A., Bilodeau, G. and Wu, G., 1994. Isotope stratigraphy, sedimentation rates, deep circulation, and carbonate events in the Labrador Sea during the last 200 kyr. Canadian Journal of Earth Sciences, 31: 63-89.

Hughes, T., 1987. Ice dynamics and deglaciation models when ice sheets collapsed, p.183-220. In W.F. Ruddiman, and H.E.J. Wright, eds., North America and adjacent oceans during the last deglaciation. Geological Society of America, Boulder.

Jennings, A.E., 1989. Late Quaternary history of Cumberland Sound, Baffin Island, Arctic Canada. Ph.D. dissertation, University of Colorado, Boulder, $319 \mathrm{p}$.

1993. The Quaternary History of Cumberland Sound, Southeastern Baffin Island: The Marine Evidence. Géographie physique et Quaternaire, 47: 21-42.

Jennings, A.E., Tedesco, K.A., Andrews, J.T. and Kirby, M.E., 1996. Shelf erosion and glacial ice proximity in the Labrador Sea during and after Heinrich events $(\mathrm{H}-3$ or 4 to $\mathrm{H}-0)$ as shown by foraminifera, p. 29-49. In J.T. Andrews, W.E.N. Austin, H. Bergsten and A.E. Jennings, eds., Late Quaternary Palaeoceanography of the North Atlantic Margins. Geological Society Special Publication 111,

Kaufman, D.S., Miller, G.H., Stravers, J.A. and Andrews, J.T., 1993. Abrupt early-Holocene (9.9-9.6 kyr BP) ice stream advance at the mouth of Hudson Strait, Arctic Canada. Geology, 21: 1063-1066.

Kennett, J.P., 1982. Marine Geology. Prentice-Hall, Englewood Cliffs, 813 p.

Kirby, M., 1996. Mid- to Late Wisconsin Ice Sheet/Ocean Interactions in the Northwest Labrador Sea: Sedimentology, Provenance, Process, and Chronology. M.Sc. thesis, University of Colorado, Boulder, 194 p.

Kirby, M.E., subm. The Observation of the Younger Dryas in Sediment Cores from the Northwest Labrador Sea: Recording Events in Cumberland Sound?

Krank, K., 1966. Sediments of Exeter Bay, Baffin Island, District of Franklin. Geological Survey of Canada Paper 66-8, $60 \mathrm{p}$.

Locke, W.W., 1986. Fine particle translocation in soils developed on glacial deposits, southern Baffin Island, N.W.T., Canada. Arctic and Alpine Research, 18: 33-43.

1987. The late Quaternary geomorphic and paleoclimatic history of Cape Dyer area, easternmost Baffin Island, N.W.T. Canadian Journal of Earth Sciences, 24: 1185-1198.

MacAyeal, D.R., 1993. Binge/purge oscillations of the Laurentide Ice Sheet as a cause of North Atlantic's Heinrich events. Paleoceanography, 8: 775784.

MacLean, B., 1985. Geology of the Baffin Island Shelf. In J.T. Andrews, ed. Quaternary Environments: Eastern Canadian Arctic, Baffin Bay and Western Greenland. Allen and Unwin, Boston, 154-177 p.
Manley, W.F. and Jennings, A.E., 1996. Radiocarbon Date List VIII: Eastern Canadian Arctic, Labrador, Northern Quebec, East Greenland Shelf, Iceland Shelf, and Antarctica. INSTAAR, University of Colorado, Boulder, Occasional Paper 50, 163 p.

Marlowe, J.I., 1966. Mineralogy as an indicator of long-term current fluctuations in Baffin Bay. Canadian Journal of Earth Sciences, 3: 191-201.

Marshall, S.J. and Clarke, G.K.C., 1996. Geologic and topographic controls on fast flow in the Laurentide and Cordilleran Ice Sheets. Journal of Geophysical Research, 101 (B8): 17,827-17,839.

Miller, G.H., 1985. Aminostratigraphy of Baffin Island shell-bearing deposits, $p$. 394-427. In J.T. Andrews, ed., Quaternary Environments: Eastern Canadian Arctic, Baffin Bay and Western Greenland. Allen and Unwin, Boston.

Miller, G.H. and de Vernal, A., 1992. Will greenhouse warming lead to northern hemisphere ice sheet growth? Nature, 355: 244-246.

Miller, G.H., Funder, S., de Vernal, A. and Andrews, J.T., 1992. Timing and character of the Last Interglacial-Glacial transition in the Eastern Canadian Arctic and Northwest Greenland, p. 223-232. In P.U. Clark, and P.D. Lea, eds., The Last Interglacial-Glacial Transition in North America. Geological Society of America, Boulder, Special Paper 270.

Moore, J., 1996. Late-Quaternary Glacial and Climatic History of the Cape Dyer Area, Eastern Cumberland Peninsula, Baffin Island, Canada: A rock magnetic and varved sediment investigation of Donard Lake. M.Sc. thesis, University of Colorado, Boulder, $175 \mathrm{p}$.

Pereira, C.P.G., Woodworth-Lynas, C.M.T. and Barrie, J.V., 1988. Iceberg scour investigations and sedimentology of the southeast Baffin Island continental shelf. Arctic , 41:221-230.

Piper, D.J.W., Mudie, P.J., Fader, G.B., Josenhans, H.W., MacLean, B. and Vilks, G., 1991. Quaternary Geology, p. 475-607. In M.J. Keen, and G.L. Williams, eds., Geology of the Continental Margin of Eastern Canada. Geological Society of America, Boulder.

Praeg, D.B., MacLean, B., Hardy, I.A. and Mudie, P.J., 1986. Quaternary geology of the southeast Baffin Island continental shelf. Geological Survey of Canada Paper 85-14, $13 \mathrm{p}$.

Ruddiman, W.F. and Mclntyre, A., 1981. The North Atlantic Ocean During the Last Deglaciation. Palaeogeography, Palaeoclimatology, Palaeoecology, 35: 145-214.

Syvitski, J.P.M., Andrews, J.T. and Dowdeswell, J.A., 1996. Sediment deposition in an iceberg-dominated glacimarine environment, East Greenland: Basin fill implications. Global and Planetary Change, 12: 251270.

Tedesco, K., 1993. Late Quaternary paleoceanography of the Northwest Labrador Sea. M.Sc. thesis, University of Colorado, Boulder, 190 p.

Vorren, T.O., Andreassen, K., Larsen, K.B. and Lebesbye, E., 1988a Glacigenic Sediments on a passive continental margin as exemplified by the Barents Sea. Marine Geology, 85: 251-272.

Vorren, T.O., Hald, M. and Lebesbye, E., 1988b. Late Cenozoic environments in the Barents Sea. Paleoceanography, 3: 601-612.

Warren, C.R., 1992. Iceberg calving and the glacioclimatic record. Progress in Physical Geography, 16: 253-282.

Yoon, S.H., Chough, S.K., Thiede, J. and Werner, F., 1991. Late Pleistocene sedimentation on the Norwegian continental slope between 67 degrees and 71 degrees N. Marine Geology, 99: 187-207. 